\title{
Current state of knowledge on the use of medical marijuana in some neurological diseases
}

\author{
Obecny stan wiedzy na temat zastosowania medycznej marihuany w wybranych \\ chorobach neurologicznych
}

Katarzyna Ziętal, Ilona Joniec-Maciejak, Dagmara Mirowska-Guzel

\section{ABSTRACT}

Cannabinoids are a group of compounds found naturally in animal and plant organisms, and in the human body. Cannabinoids can be extracted from cannabis varieties, differing in morphological structure. In addition to cannabinoids, cannabis contains a number of active compounds, including terpenes, flavonoids, phenanthrenes, spiroindanes, and dihydrostilbens.

Epilepsy, Parkinson's disease and multiple sclerosis are neurological diseases the symptoms of which dramatically impair patients' quality of life. If standard pharmacotherapy does not bring the expected results, attempts are made to introduce alternative methods of therapy. One of them is the use of cannabis-based preparations containing two main active substances, i.e. THC and CBD. Preliminary results of clinical trials with cannabis-based preparations indicate a potential therapeutic effect in reducing the frequency of seizures in drug-resistant epilepsy among children. However, this needs to be proven in further properly planned studies. In patients with MS, their use may reduce pain and spasticity. In Parkinson's disease, most of the data on the potential benefits of cannabis-based preparations comes from preclinical studies.

The purpose of the studies was to confirm the effectiveness of the use of "medical cannabis." However, the results of the studies are not clear. On this account, cannabis use is still not a legalised method of therapy in most countries. However, cannabis is more and more often used in severe cases of resistance to treatment.

The aim of this paper is to critically analyse contemporary scientific data on the possible use of medical cannabis. 


\section{STRESZCZENIE}

Kannabinoidy są grupą związków występujących naturalnie w organizmach zwierzęcych i roślinnych, są również obecne w organizmie człowieka. Kannnabinoidy izoluje się z różnych gatunków konopi, różniących się odmienną budową morfologiczną. Oprócz kannabinoidów rośliny te zawierają szereg związków aktywnych, między innymi: terpeny, flawonoidy, fenantreny, spiroindany, dihydrostilbeny.

Padaczka, choroba Parkinsona oraz stwardnienie rozsiane są chorobami neurologicznymi, których objawy w dramatyczny sposób pogarszają jakość życia pacjentów. W sytuacji, kiedy standardowa farmakoterapia nie przynosi oczekiwanych rezultatów podejmuje się próby wprowadzenia alternatywnych metod terapii - jedną $\mathrm{z}$ nich jest zastosowanie preparatów na bazie konopi, zawierających dwie główne substancje czynne: THC oraz CBD. Wstępne wyniki badań klinicznych z zastosowaniem preparatów na bazie konopi wskazują na potencjalny efekt terapeutyczny w redukcji częstości napadów w przypadku padaczki lekoopornej u dzieci, co wymaga jednak udowodnienia w dalszych prawidłowo zaplanowanych badaniach. U pacjentów z SM ich zastosowanie może powodować zmniejszenie nasilenia bólu oraz spastyczności. W przypadku choroby Parkinsona większość danych dotyczących potencjalnych korzyści stosowania preparatów na bazie konopi pochodzi z badań przedklinicznych.

Wyniki badań, których celem było potwierdzenie skuteczności stosowania „medycznej marihuany” w tych jednostkach chorobowych nie są jednoznaczne. $Z$ tego powodu marihuana nadal w większości krajów nie jest zalegalizowaną metodą terapii. Coraz częściej jednak wydaje się zgodę na jej zastosowanie w ciężkich przypadkach opornych na leczenie. Celem prezentowanej pracy przeglądowej jest próba krytycznej analizy aktualnych danych naukowych dotyczących możliwości zastosowania medycznej marihuany.

\section{Introduction}

Cannabis is an annual angiosperm in the Cannabaceae family. In the US pharmacopoeia, cannabis is defined as dried female inflorescences without thick stems and large leaves, with a fruit content of less than 10 per cent. There are three species of cannabis: Cannabis sativa L., Cannabis indica L. and Cannabis ruderalis. The distinction between the species is due to psychotropic effect they produce and not due to their morphological structure. Cannabis is commonly used for medical, cosmetic and food purposes. They have a positive effect on mood as they create a feeling of joy and euphoria, but due to their potential addictive properties and the risk of aggression in those who use it, many countries have introduced bans or restrictions on their use. Only in recent years has this group of compounds been studied for use in various disease entities (Vetulani and Mazurek, 2016).

\section{Literature review}

\section{History of cannabis}

Cannabis is one of the oldest cultivated plants. The history of Cannabis indica dates back to at least 4,000 BC in China where it was used to produce rope, paper and textiles. The fruit of the plants provided food. Cannabis was believed to relieve pain and exert anti-rheumatic effect. It was used as a remedy against constipation, malaria and reproductive disorders (Touwn, 1981).

In India, cannabis played an even more prominent role. This may have been due to the relationship between

religion and the plant since cannabis was seen as a sacred plant, and a source of happiness, joy and freedom. It was believed to have analgesic, sedative, anticonvulsant, antiparasitic, anaesthetic, appetite-stimulating, anti-inflammatory, antispasmodic, diuretic, antitussive and expectorant effect. Cannabis was used to treat epilepsy and rabies, and as an antibiotic in various skin infections, tuberculosis, digestive problems and respiratory infections (Mathre, 1997; Zuardi, 2006). In Europe, archaeological traces indicate that cannabis was cultivated in the period preceding the era we currently live in. Irish physician William B. O'Shaughnessy began to popularise the plant as a therapeutic agent. Based on the knowledge gained during his travels, he studied the plant and evaluated its effects in animals and humans. On the basis of his discoveries, he wrote a book which became the primary source of knowledge about cannabis. As a result, doctors and researchers started to continue his research. In the mid-19 $9^{\text {th }}$ century, the psychoactive potential of cannabis was accurately described by Jacques-Joseph Moreau, a French psychiatrist who studied its effects in himself and patients of a psychiatric hospital (Russo, 2001). Over time, various cannabis preparations and extracts were made and sold. At the beginning of the $20^{\text {th }}$ century, Charles E. de M. Sajous and Louis T. de M. Sajous described therapeutic properties of cannabis in Sajous's Analytic Cyclopedia of Practical Medicine.

In the first decades of the $20^{\text {th }}$ century, the use of cannabis became less common. This may have been due to an increase in the production of modern medicines designed to treat specific conditions. There were also a number of legal restrictions due to the psychoactive properties of cannabis. The renewed interest in cannabis at the end 
of the $20^{\text {th }}$ century was because its chemical composition could be more thoroughly analysed and the purity of the extracted active substances could be increased (Mikuriya, 1969).

\section{Industrial uses}

According to the Act of 29 July 2005 on counteracting drug addiction, in Poland, industrial hemp encompasses fibrous Cannabis sativa L. in which the THC content in flowering or fruiting upper shoots (monoicous plant with resin) does not exceed $0.2 \%$ of the dry mass (Act of 29 July 2005 on counteracting drug addiction). Industrial hemp is used, inter alia, to produce fibres. Its cultivation is popular due to its resistance to pests and drought as well as lower water demand as compared to cotton, for example. The food industry uses hemp oil, which is rich in nutrients (Siudem et al., 2015). CBD content in the oil varies depending on the growing conditions (Leizer et al., 2000).

In the cosmetic industry, hemp oil is used because of its moisturising and antiseptic properties (Tennstedt and Saint-Remy, 2011). It is believed to have therapeutic properties in the treatment of acne vulgaris (Oláh et al., 2014). In the construction industry, hemp is used to obtain materials for thermal insulation and mortar. Hemp oil is also used to obtain diesel, fuel biomass and high-strength bioplastics (Vetulani and Mazurek, 2016; Frassinettia et al., 2018; Kilpeläinenb et al., 2019).

\section{Cannabinoids}

Cannabinoids are the basic active compounds which affect cannabinoid receptors. There are 3 types of cannabinoids: cannabinoids of plant origin (phytocannabinoids), cannabinoids produced by animals and cannabinoids produced by humans (endocannabinoids and synthetic cannabinoids).

Phytocannabinoids are terpenoid compounds extracted from the resin. They include about 60 substances. They are mainly synthesised in female cannabis inflorescences. Most of them are located in the unpollinated flowers. They occur in plant materials, mainly in the form of inactive carboxylic acids, e.g. tetrahydrocannabinol acid (THCA-A) and cannabidiol acid (CBDA) which, at high temperatures, are decarboxylated to active forms: trans- $\Delta^{9}$-tetrahydrocannabinol (THC, Fig. 1), and cannabidiol (CBD, Fig. 2).

Tetrahydrocannabinol (THC) is a compound extracted from Cannabis sativa. It is a psychoactive, aromatic terpenoid with a phenolic group. THC is a psychoactive component of cannabis. It causes euphoria and has antiemetic, analgesic, antioxidant and anti-inflammatory effect (Kaczmarczyk-Sedlak et al., 2017). THC is soluble in fats and this why it accumulates mainly in adipose tissue, lungs, liver and spleen after administration. Its content in cannabis varies depending on the conditions of cultivation, age, genetic modification and type of plant tissue. The content range is wide from 0.001 to $10 \%$. Therefore a single cannabis species divides into several varieties. Individuals with THC concentrations below $1 \%$ are used in industry while those with higher THC are intended for cannabis production (Gaoni and Mechoulam, 1964). The inflorescences and resin contain the highest THC concentration while the leaves - the least concentration (Siudem et al., 2015; Silska, 2017; The Advisability and Feasibility of Developing USP Standards for Medical Cannabis: https://www.uspnf.com/sites/ default/files/usp_pdf/EN/USPNF/usp-nf-notices/usp_ stim article_medical_cannabis.pdf).

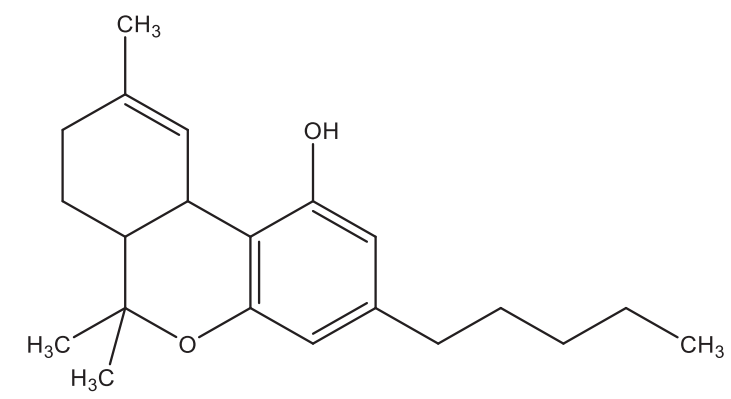

Figure 1. $\Delta^{9}$-tetrahydrocannabinol (THC)

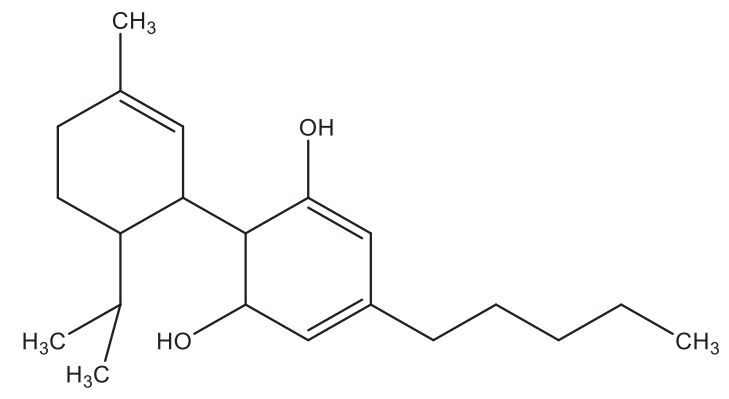

Figure 2. Cannabidiol (CBD)

Cannabidiol (CBD) is a non-psychoactive compound. It is considered to be the most common phytocannabinoid. It slightly differs in structure from THC. However, due to these slight differences, both compounds show the antagonistic effect. Compared to THC, the CBD affinity is lower for $\mathrm{CB} 1$ receptors and higher for $\mathrm{CB} 2$ receptors. This is why CBD has more influence on the immune system than on the nervous system (Adams et al., 1940; Siudem et al., 2015).

\section{Endocannabinoids}

Endocannabinoids are a group of compounds found in animals, including humans. They are formed from lipid precursors, mainly long-chain fatty acids, such as arachidonic acid. Arachidonic acid is included in the phospholipids of the membranes of nerve cells and thus significantly affects the functioning of the nervous system. 
Unlike typical neurotransmitters, endocannabinoids are not stored in the body. They are produced in response to incoming calcium ions and membrane depolarisation. The best-known and best-studied endocannabinoids include anandamide (AEA) and 2-arachidonyloglycerol (2AG). The compounds are structurally similar to each other, but are synthesised and degraded by means of different enzymatic pathways. Anandamide stimulates receptors and ion channels while 2-arachidonyloglycerol mainly acts as a neuromodulator. The compounds are hydrolysed under the influence of relevant enzymes and induce various cellular processes (Mauryaa and Velmurugan, 2018; Kaczmarczyk-Sedlak et al., 2017).

\section{Endocannabinoid system}

Endocannabinoids together with cannabinoid receptors and their endogenous ligands, enzyme complexes and regulatory proteins form the endocannabinoid system (eCB). Endocannabinoids have different effects on the receptors. Due to their agonistic properties, the system is stimulated by activating two types of receptors. In 1990, the cannabinoid receptor type 1 (CB1) was identified and cloned (Gerard et al., 1991). In 1993, the cannabinoid receptor type 2 (CB2) was identified and cloned (Munro et al., 1993). The receptors occur in various areas of the human body and perform specific functions in pathophysiological processes. They are conjugated with protein $\mathrm{G}$ and act as modulators of neurotransmitter release. $\mathrm{CB} 1$ receptors are mainly located at the ends of nerve cells and mediate transmitter release. CB2 receptors have immunomodulating effect and regulate the activity of cytokines and migration of immune cells. Seeing a huge potential in this respect, researchers started to modify the activity of the receptors to achieve the intended therapeutic effect.

The endocannabinoid system is very complex because it is responsible for a variety of functions and the activity of its compounds is often antagonistic. Even slight disorders of this system cause the development of pathological states in the cardiovascular system, central nervous system, immune system, respiratory system, digestive system and skin. Knowing how cannabinoid receptors work and how they interact with neurotransmitters, we can modify physiological processes. Moreover, if the synthetic antagonists of these receptors are used during the excessive stimulation of the endocannabinoid system, body homeostasis can be restored (Pertwe, 2006; Scholten, 2006; Silska, 2017).

\section{Cannabis}

Cannabis is obtained from varieties having a high THC content (0.5-9\%). Due to the high concentration of THC, the product has been found to be capable of causing psychotic reactions in accordance with legislation. Cannabis is obtained from leaves of a diclinous variety with flowering and fruiting upper shoots, mainly from unpollinated females. No processing is needed to obtain it. Most often, it is obtained from dried parts of the plant which are either burned, like cigarettes, or brewed. The effect of cannabis depends on the dose used, the way it is administered, the frequency of use and the mental state. The most popular forms of cannabis intake include oral administration and inhalation. The inhalation is the most effective and immediate method (with the effect after just 5 minutes). This is because cannabis enters the body in its unchanged form and then passes through the lungs directly into the bloodstream. In the case of oral intake, the effect occurs after about 30-90 minutes. Smoking (similar to tobacco smoking) is the most popular way cannabis is used. This way is dangerous due to harmful compounds which are formed during burning. THC, an active substance in the cannabis reaches the lungs in $20-70 \%$ and the brain in $5-24 \%$. Regular smoking of $3-5$ weeds per day causes drug tolerance while occasional smoking causes the effect after the intake of 2-3 mg of THC. The estimated lethal dose of $\mathrm{THC}$ ranges from $15 \mathrm{~g}$ to $70 \mathrm{~g}$.

The cannabis can be "medical" or "recreational." What makes them different is the purpose they are used for. This distinction has legal implications. The substance derived from cannabis for medical purposes, giving standardised products and cultivated in strictly controlled conditions, is treated as a "medical cannabis." The term "recreational cannabis" is mainly used to refer to the relaxation effect of cannabis use, which may be accompanied by a medical effect (Hall and Degenhardt, 2009; Vetulani, 2014).

\section{Undesirable effects of cannabis}

The negative and positive effects of cannabis are the subject of a number of studies and discussions. It is not without reason that the use of cannabis for recreational purposes is prohibited. This is the case because THC exhibits the psychoactive effect. The cannabis use, particularly popular among young people, is aimed achieving relaxation and euphoria. However, the cannabis use may also cause side effects, such as disturbances in consciousness and perception, delusions, anxiety, concentration disorders and delayed reactions which pose a risk of accidents. The cannabis use is often accompanied by alcohol and drugs, such as cocaine and amphetamine, which lead to the accumulation of most adverse effects. Studies have shown that cannabis has a negative effect on the cardiovascular system. Those who use it can experience tachycardia and changes in blood pressure, which, in turn, can cause dizziness, for example. Cannabis also has a negative effect on the respiratory system. The tar accumulated during smoking affects lung function and may lead to bronchial damage or increase the likelihood of developing respiratory cancer. It also affects the birth 
weight (causes low birth weight) of newborn babies in mothers who used it during pregnancy. Long-term use of cannabis can lead to somatic disorders and psychosis. People who used high doses of cannabis may experience withdrawal symptoms (anxiety, nervousness, insomnia) after they stopped using it. It has lower psychotic effect than alcohol, but this does not mean that its use is safe and without health consequences (Dabrowska et al., 2012; Wojnar, 2018).

\section{Cannabis legalisation}

The cannabis legalisation was one of the most controversial public health issues. Since cannabis was illegally used over the years of prohibition on its use, many countries were forced to update their policies on cannabis legalisation. In the United States of America, medical use of cannabis is legal in 33 states, while its recreational use is legal in 11 states (Collingwood et al., 2018; State Medical Marijuana Laws, National Conference of State Legislatures, 2018). In most EU countries, the possession of cannabis for recreational purposes is prohibited and considered a crime. Currently, with the consent of the relevant state authorities, more and more countries allow its use, but only for medical purposes. The only EU countries in which the possession of recreational cannabis for personal use is permitted in quantities strictly defined by legislation are Belgium, the Czech Republic, the Netherlands and Spain. In the Netherlands, there are also special places called coffee-shops in which it can be legally purchased (Bifulco and Pisanti, 2015). Uruguay is the first country in the world to legalise cannabis, its use, cultivation and trade in 2017. Its law sets the maximum amount that can be purchased in pharmacies ( 40 grams per month) and requires the holder to be of legal age (legality of marijuana in the world: https://www. cannabisnews.pl/legalnosc-marihuany-na-swiecie/).

Poland is a country in which the possession of cannabis for recreational purposes is illegal and considered a crime. According to the Act issued by the Polish Parliament in 2017, cannabis can only be used for therapeutic purposes (Act of 7 July 2017 amending the Act on counteracting drug addiction and the Act on reimbursement of drugs, food products for special dietary purposes and medical devices). Any doctor may issue a prescription for it, but it is not reimbursed.

\section{Analysis of experimental and clinical data determining the effects of medical cannabis in selected conditions}

The use of cannabis and its derivatives as medicinal products is very controversial. There are two different views on the issue in society; some people believe that it is a drug and demand restrictive rules on their use while others refer to its therapeutic properties and expect its legalisation.
A number of experimental and clinical studies on cannabis have been carried out so far to confirm the effectiveness and safety of its use. CBD and, less commonly, THC are the main active compounds of cannabis thought to be effective for medical purposes. The preparations using these compounds contain only one component: $\mathrm{CBD}$ or $\mathrm{CBD} / \mathrm{THC}$ mixture at a rate of 1:1. Currently, there are five pharmaceutical raw materials from medical cannabis registered in Poland (https://mgr.farm/aktualnosci/juz-piec-surowcow-farmaceutycznych-z-medycznej-marihuany-zarejestrowanych-w-polsce/) and only one cannabinoid preparation - Sativex (Nabiximols), a mixture of THC and CBD for the supportive treatment of spastic tension in patients with multiple sclerosis. The decision as to whether the preparation can be introduced as an addition to standard pharmacotherapy is made by the physician who bears full responsibility for the potential risk of use (Bergamaschi et al., 2011; Wachowiak et al., 2016).

The results of the studies indicate that cannabis can be used to treat or alleviate the symptoms of a number of diseases, such as epilepsy, multiple sclerosis, Alzheimer's disease, Parkinson's disease, glaucoma, rheumatoid joint pain, cancer, gastrointestinal diseases, AIDS, metabolic disorders, asthma and many others (Motyka and Marcinkowski, 2014).

\section{Epilepsy}

Epilepsy is one of the most common neurological diseases. It is characterised by epileptic seizures which result from functional impairment in the brain. Epilepsy is caused by excessive bioelectrical discharge of nerve cells. Treatment of epilepsy is based on pharmacotherapy applied throughout the duration of the disease. If the use of 2 or 3 drugs is unsuccessful, oral medical cannabis can be used as an alternative treatment (Rozenek and Shepherds, 2010).

In 2015, Press et al. presented the results of surveys conducted among parents of 75 children with epilepsy. The surveys asked, inter alia, about the type and frequency of seizures. Children were treated daily with oral cannabis preparations as an addition to standard pharmacotherapy. The observation period was 1-4 months. Out of 75 children, parents of 43 of them (57\%) reported a decrease in seizure frequency. Additionally, their caretakers observed improved concentration (33\%) and speech (11\%). Based on the results of the surveys, the authors suggested that the administration of oral cannabis preparations in children with epilepsy resulted in the health improvement. However, this conclusion is only based on a subjective assessment of parents since no reliable clinical trials were conducted (Press et al., 2015).

Porter and Jacobson analysed the use of cannabidiol-enriched cannabis preparations in 19 children with drug-resistant epilepsy (children aged 2-16 years) in 
whom previously used antiepileptic drugs did not produce the expected results. Children were given CBD preparations $(0.5 \mathrm{mg} / \mathrm{kg} /$ day to $28.6 \mathrm{mg} / \mathrm{kg} /$ day) for the period of 1 to even 12 months. In a survey, their parents were asked 24 questions about, inter alia, clinical factors, including the type of seizures and effects of CBD use. Sixteen parents (84\%) reported a decrease in the frequency of seizures in their children. Two children (11\%) experienced total seizure decline, 8 children (42\%) experienced over $80 \%$ reduction in seizure frequency and 6 children $(32 \%)$ experienced $25-60 \%$ reduction in seizure frequency. Parents reported the improvement in children's quality of life, due to fewer seizures, as another beneficial effect resulting from the use of the preparation. The side effects of the therapy included sleepiness and fatigue. The authors concluded that the results of the study prove the effectiveness of CBD in treating children with drug-resistant epilepsy. However, the data obtained, based only on the assessment of parents and assuming various observation periods, are not sufficient to confirm the effectiveness of the treatment (Porter and Jacobson, 2013).

In 2017, Hussain et al. presented the results of the study in which they analysed the effects of cannabidiol (CBD) at a dose of $4.3 \mathrm{mg} / \mathrm{kg} /$ day in children with Lennox-Gastaut syndrome or West syndrome. The study included 117 children of different ages. The average observation period was 7 months. Parents of the children were asked a series of questions about the characteristics of epileptic syndrome, classification, basic aetiology, efficacy of pharmacotherapy, frequency of adverse effects before and after exposure to CBD, and duration of CBD use. Out of 117 parents, 100 of them (85\%) reported a decrease in seizure frequency, while 16 of them $(10 \%)$ reported the cessation of seizures. Adverse effects included increased appetite while improved sleep, mood and concentration were reported as additional benefits by more than $50 \%$ of patients. The results of the study indicated the effectiveness of CBD in the treatment of drug-resistant epilepsy in children, but it is necessary to conduct clinical trials to provide objective evidence of this effect in the group of patients of different ages (Hussain et al., 2015).

Thiele et al. conducted a randomised, double-blind, placebo-controlled study to analyse the efficacy of cannabidiol (CBD) in people with Lennox-Gastaut syndrome. The study was conducted in 24 clinical centres in the USA, the Netherlands and Poland. 171 patients aged 2-55 years participated in the study. The study participants had to meet the following criteria: more than one type of epileptic seizure over a period of more than half a year, 2 atonic seizures per week during the 4-week onset of the disease, lack of effectiveness of at least 2 drugs. Patients were randomly assigned to two groups. One group was given $20 \mathrm{mg} / \mathrm{kg} /$ day of oral CBD for 14 weeks while the other received placebo. In the study group, a decrease in monthly seizure frequency by an average of $44 \%$ was observed ( 3 people in the CBD group experienced complete remission) while in the placebo group - by $22 \%$. Adverse effects, such as drowsiness, diarrhoea, fever, decreased appetite and vomiting, occurred in 86 patients in the CBD group and 59 out of 85 patients (69\%) in the placebo group. The results of the study suggested the efficacy of CBD in the treatment of patients with epileptic seizures resulting from Lennox-Gastaut syndrome. However, due to the wide age gap, the reliability of the results is significantly limited and it is not possible to draw clear conclusions (Thiele et al., 2018).

Devinsky et al. conducted a randomised study to analyse the effects of cannabidiol. The study included 214 patients aged 1-30 years with a severe, drug-resistant form of epilepsy. The study was conducted in 11 centres in the USA over a 12-month period. Initially, the study participants received CBD at a dose of $2-5 \mathrm{mg} / \mathrm{kg} /$ day. This dose was gradually increased to a maximum of $25 \mathrm{mg} / \mathrm{kg}$ or $50 \mathrm{mg} / \mathrm{kg}$ per day. 162 out of 214 patients $(76 \%)$ were included in the safety and tolerability analysis after the first dose of CBD while 137 patients (64\%) were included in the effectiveness analysis. In the group of patients in which CBD safety was analysed, 33 patients $(20 \%)$ had Dravet syndrome and 31 (19\%) had Lennox-Gastaut syndrome. Other patients had severe forms of epilepsy of different aetiology. Adverse effects were reported in 128 of 162 patients (79\%) participating in the CBD safety study. Adverse effects, reported in more than $10 \%$ of patients, included drowsiness, decreased appetite, diarrhoea, fatigue and convulsions. Five patients (3\%) stopped the treatment due to the occurrence of an adverse event. Serious adverse events were reported in 48 patients (30\%), including one death (considered unrelated to the drug used in the study). 20 patients (12\%) experienced severe adverse effects. The average monthly seizure frequency decrease was $36.5 \%$. The results of the studies indicated that it is possible to reduce the frequency of seizures in people with drug-resistant epilepsy using $C B D$, but it is necessary to conduct controlled and randomised studies (Devinsky et al., 2016).

In 2017, Devinsky conducted another study. The study included 120 people aged 2-18 years with drug-resistant Dravet syndrome. The study was conducted using the double-blind method with a placebo-controlled group. The study participants received an oral CBD solution at a dose of $20 \mathrm{mg} / \mathrm{kg}$ bodyweight per day, as an additional treatment, or placebo. The study was conducted over a period of 14 weeks. A decrease in seizure frequency was observed from about 12 to 6 per month in the CBD group and from 12 to 11 per month in the placebo group. Out of patients with at least $50 \%$ decrease in seizure frequency, $43 \%$ of them used CBD and $27 \%$ of them were given placebo. The overall condition improved in $62 \%$ of patients in the CBD group and in $34 \%$ of patients in the placebo group. The frequency of seizures was significantly reduced when CBD was used. No changes in the group of patients with non-convulsive seizures were 
observed. In $5 \%$ of patients in the CBD group, the complete remission was observed. Adverse effects were more frequent in the CBD group than in the placebo group and included diarrhoea, vomiting, fatigue, fever, drowsiness and abnormal functional liver test results. There were also more cases of discontinuation of therapy in the CBD group. The results of the study confirmed a decrease in the frequency of epileptic seizures in children using CBD in a wide range of age groups. However, the use of the drug was often caused the occurrence of adverse effects (Devinsky et al., 2017).

The most recent recommendations for the treatment of adult epileptic seizures based on the guidelines published by the International League Against Epilepsy and the American Academy of Neurology have not included the possibility of using cannabis preparations despite a number positive, though ambiguous, results of scientific research. It has only been indicated that CBD-based preparations can be used as an alternative treatment method if standard therapy is ineffective (Jędrzejczak et al., 2019).

The American Epilepsy Society (AES), bringing together clinicians and scientists, monitors all research regarding the treatment of epilepsy with medical cannabis and seeks to develop safe and effective rules for the treatment. Until recently, there have only been single reports of effective CBD in epilepsy. Recently, the results from randomised, double-blind, and controlled clinical trials on the use of highly purified and concentrated CBD have been published. The results indicated moderate CBD efficacy in the treatment of Lennox-Gastaut syndrome and Dravet syndrome (AES, Position Statement on Cannabis as a Treatment for Patients with Epileptic Seizure, February 2019). With the support of AES, the Food and Drug Administration (FDA) approved the prescription-only medicine as an oral solution of cannabidiol, Epidiolex. However, the need to plan and conduct multicentre, controlled and methodologically correct tests for all cannabis products is still emphasised. The results of these studies could help to establish the dosage, and identify adverse effects and potential interactions with other drugs (Giancaspro et al., https://www.uspnf.com/ sites/default/files/usp_pdf/ EN/USPNF/usp-nf-notices/ usp_stim_article_medical_cannabis.pdf).

Interactions between antiepileptic drugs (LPP) and CBD preparations is one of the key aspects which should be assessed before CBD is introduced into the therapy. Gaston et al. analysed possible interactions between CBD and antiepileptic drugs. The study included 39 adults and 42 children with drug-resistant epilepsy who had been taking drugs regularly for at least one month before the study. The initial dose of CBD was $5 \mathrm{mg} / \mathrm{kg} / \mathrm{day}$. The dose was increased every 2 weeks by $5 \mathrm{mg} / \mathrm{kg} /$ day to a maximum of $50 \mathrm{mg} / \mathrm{kg} /$ day. LPP doses were determined based on adverse symptoms or the exceedance of tolerable level of doses in serum. The results obtained by the authors did not allow to draw a clear conclusion about the interactions between LPP and cannabis preparations. Almost all observed average changes in LPP levels were within the accepted therapeutic range. In patients using valproate, increased AST/ALT values were observed, indicating the need to monitor serum LPP levels, but also to perform liver tests during CBD administration (Gaston et al., 2017).

The results of some studies have shown that high doses of CBD (up to 1,500 mg/day) are well tolerated in humans. Other studies have shown completely opposite results. Adverse effects, such as inhibition of drug metabolism, cytotoxicity and reduced receptor activity were observed. The discrepancies indicate the need to determine the optimal dose, safe for humans (Bergamaschi et al., 2011).

The mechanism of medical activity of cannabis in epilepsy is not fully known. So far, its effectiveness as an intracellular calcium ion modulator has been proven. Calcium ion homeostasis and metabolic activity are the two key factors which determine the viability of neurons, depending on the functioning of mitochondria. Even small deficits in mitochondrial function may have negative effects ultimately leading to degenerative processes. It is believed that the regulation of calcium ion homeostasis via CBD is bidirectional, depending on cellular excitability. Under physiological conditions, CBD increases the concentration of calcium ions inside the cells. Under high excitability conditions, it reduces their concentration. The antagonistic activity of CBD helps regulate calcium homeostasis and ensure proper cellular excitability, preventing abnormal bioelectrical discharge. It has also been shown that endocannabinoids play an important role in the control of synaptic transmission and the control of neuronal migration speed. In the central nervous system, CB1 receptors are presynaptically expressed on both glutamate- and GABA-ergic interneurons, and their activation inhibits synaptic transmission, including the release of glutamate. It is also suggested that CBD acts as a serotonin reuptake inhibitor and antagonist of $\mathrm{G}$ protein-coupled receptor 55 (GPR55) (Foldy, 2006; Ryan et al., 2009; Perucca, 2017).

\section{Multiple sclerosis}

Multiple sclerosis (sclerosis multiplex, MS) is a chronic, demyelinating inflammatory disease of the central nervous system. The use of medical cannabis is one of the ways to alleviate the symptoms of the disease, mainly the pain resulting from spasticity and inflammatory reaction (Świątek, 2016).

The therapeutic effects of medical cannabis are probably due to the functional role of cannabinoid receptors (CB1 and CB2) making up the endocannabinoid system. The CB1 receptor mediates the transmission of nerve signals, while the CB2 receptor takes part in 
immunomodulating processes, regulating the activity of immune system cells.

The results of the tests in rats indicate the mitigation of tremor and spasticity under the influence of THC and agonists of $\mathrm{CB} 1$ and $\mathrm{CB} 2$ receptors. In clinical trials, the role of $\mathrm{CB} 1$ receptor was analysed as it can inhibit the neurodegenerative process in MS. As a modulator of lymphocyte and macrophage expression, the CB2 receptor probably has the ability to regulate the inflammatory process which is the main cause of demyelination and impairment of signal transmission between neurons in multiple sclerosis. In the therapy of MS, endocannabinoids, i.e. 2-AG and AEA which are bioactive lipids regulating CNS function, are thought to play an important role. Introduction of monoacylglycerol lipase inhibitor (MAGL), which inhibits endocannabinoid degradation, prevents degeneration of nerve cells and protects oligodendrocytes to maintain myelin integrity and correct transmission of nerve signals (Baker et al., 2001; Bernal-Chico et al., 2015; Przybek et al., 2017; Chiurchiùa et al., 2018).

In a randomised, placebo-controlled, double-blind study, Wade et al. analysed the effect of cannabis-based preparation on the alleviation of MS symptoms. The study was conducted in 3 centres in Great Britain. The study included 160 patients, with diagnosed MS and varying course of disease, who had one or more of the following symptoms: spasticity, cramps, pain, tremor, and bladder problems, took regular medication and had no relapses for the last 4 weeks. For six weeks, half of the patients were given an oral cannabis-based preparation (Nabiximols) at doses of 2.5-120 mg/day. Other patients were given placebo. Patients recorded the results of the Visual Analogue Scale (VAS) for the most troublesome symptom and the evaluation of other symptoms, disability, cognitive dysfunction, mood, sleep and fatigue. The results of the study indicated a decrease in the frequency of occurrence of the most persistent symptom (mainly spasticity). This was more common in the cannabinoid group than in the placebo group. No significant effects on cognitive functions and mood were found. Adverse effects were generally mild and included mainly dizziness and headaches. However, in the summary of the study, it was pointed out that the mechanism of THC and CBD activity responsible for this therapeutic effect needs to be thoroughly investigated (Wade et al., 2004).

In another randomised, double-blind study, Wade et al. evaluated the efficacy and safety of long-term use of cannabis-based preparations. The study included 137 patients with any type of MS who had at least one of the following symptoms: cramps, spasticity, pain, tremor and bladder problems. They were given an oral mucosal spray. A single dose of the spray contained $27 \mathrm{mg} / \mathrm{ml}$ of THC and $25 \mathrm{mg} / \mathrm{ml}$ of CBD. Patients determined the daily dose on their own, depending on whether the symptoms subsided, and adverse effects occurred. Patients were evaluated every eight weeks, using mainly the VAS scale for an average of 434 days. 58 patients (42.3\%) withdrew from the study after 225 days on average due to the lack of efficacy of the applied preparation or the occurrence of adverse effects. During the study, 292 adverse reactions were reported, including: oral pain, nausea, diarrhoea, dizziness, of which over $80 \%$ were mild to moderate. Three patients had severe adverse effects resulting from the use of the preparation: gastroenteritis, aspiration pneumonia, epileptic seizure or loss of balance. In 25 patients, the preparation was discontinued for 2 weeks, but it did not cause more severe withdrawal symptoms. In other patients, the alleviation of MS symptoms was reported. However, it was not possible to accurately determine the efficacy of the cannabis preparation and additional studies were needed to address the adverse effects of some patients (Wade et al., 2006).

In 2010, Colin et al. presented the results of the study in which they analysed the effect of cannabis preparation on the alleviation of spasticity in MS patients. During the 15-week double-blind study with 337 patients, Nabiximols was used. The results indicated a significant reduction in spasticity in the group using this preparation as compared to the placebo group and the adverse effects were generally mild (Collin et al., 2010).

The aim of the research conducted by Marková et al. was to determine the efficacy of cannabinoid preparation as an additional element of pharmacotherapy in MS patients with moderate to severe spasticity. A double-blind study included 191 patients. The study participants used a spray with THC and CBD content at a rate of 1:1 for 4 weeks. In the second phase of the study, 106 patients were randomly assigned to a study group or placebo group. The subjects in the study group used the preparation for 12 weeks. No serious adverse effects were reported in the study. The results showed its effectiveness in reducing spasticity in MS patients. When used in combination with pharmacological treatment, it was found to be more effective in reducing spasticity than pharmacotherapy itself (Markovà et al., 2019).

Langford et al. conducted a study in which they analysed the effect of cannabis-based preparations in relieving neuropathic pain in MS patients. The study included 339 MS patients. The study participants were randomly assigned to a placebo group and a group using THC and CBD preparation. The observation period was 14 weeks. The results were inconclusive. The pain relief effect observed in the placebo group and the study group was comparable. The results of the second phase of the study were contrary to the expectations as no effects were obtained as compared to the placebo group upon the extension of the time of pain treatment with the THC and CBD preparations. Therefore, it is necessary to conduct further clinical trials to unequivocally determine how active compounds in cannabis reduce neuropathic pain (Langford et al., 2013). 
The American Academy of Neurology presented the results of a review of studies from 1948-2013, which included clinical trials and animal experiments on the use of medical cannabis as a method to alleviate symptoms of multiple sclerosis. Based on an analysis of 34 studies, the following conclusions were made about the oral cannabis preparations:

- they are effective/probably effective in reducing spasticity,

- they are probably ineffective in inhibiting tremor,

- they are probably ineffective/effective in bladder disorders,

- they are effective/probably effective in reducing pain, excluding neuropathic pain (Koppel et al., 2014).

The clinical trials concerned the use of cannabis preparations (THC/CBD) in patients with multiple sclerosis as an addition to standard pharmacotherapy. No effect of cannabinoids on MS progression were reported. The symptoms of the disease, mainly spasticity and pain, alleviated. Some patients did not have any adverse effects while others experienced pain, dizziness, vomiting and nausea. The efficacy and safety of long-term use of the preparation could not be clearly defined. It is not known whether drug tolerance to cannabinoids occurs during prolonged use. Potential drug interactions are also unknown.

\section{Parkinson's disease}

Parkinson's disease (PD) is one of the most common neurodegenerative diseases in which dopaminergic cells of the nigrostriatal pathway degenerate. The treatment of PD is symptomatic. When a patient has difficulties in daily functioning, pharmacotherapy is introduced. In most patients, appropriately selected pharmacotherapy gives quite a good therapeutic effect and delays the occurrence of motor complications. Unfortunately, in the advanced stage of $\mathrm{PD}$, drugs cease to be effective. Given the mechanisms of degeneration of dopaminergic cells and the mechanisms of action of the endocannabinoid system, it can be assumed that CB1 receptors can produce a neuroprotective and anti-inflammatory effect (Bogucki et al., 2014; Gaweł and Potulska-Chromik, 2015).

Mounsey et al. analysed the effect of increased concentration of 2-arachidonoylglycerol (2-AG) in the MPTP neurotoxin-induced model of PD which occurs in mice. 2-AG was administered at doses of 3 and $5 \mathrm{mg} /$ $\mathrm{kg}$. Additionally, an inhibitor of enzymatic degradation of 2-AG was applied. The results of the study indicated that 2-AG inhibits MPTP-induced neurodegeneration, which proves that the endocannabinoid system may have been involved in this neuroprotective activity (Mounsey et al., 2015).

Other studies have shown that the use of CB1 receptor agonists in the experimental model of $\mathrm{PD}$ improves the motility of animals, though probably through interactions with adenosine A2A and 5-HT receptors rather than dopaminergic mechanisms (Kreitzer and Malenka, 2007). The use of CB1 receptor antagonists was more effective and resulted in improved motor function. It reduced akinesis and motor impairment in experimental models of PD (Gonzalez et al., 2006; García et al., 2011).

The endocannabinoid system is thought to have an effect on L-DOPA- induced dyskinesias, although the results of preclinical trials were controversial indicating that both CB1 receptor agonists and antagonists are represented as anti-dyskinesia agents (van der Stelt et al., 2005).

Few clinical trials have been carried out so far to analyse the effects of cannabinoids on motor and non-motor symptoms in PD patients. In a small, randomised, placebo-controlled, double-blind study, the effect of CB1 and CB2 receptor agonists on the occurrence of L-DOPAinduced dyskinesias in PD patients was analysed. The decrease in the symptom and total time of dyskinesia was demonstrated (Sieradzan et al., 2001). In another small, randomised, double-blind, four-week study, the effect of oral administration of cannabis extract (containing $1.25 \mathrm{mg}$ of CBD and $2.5 \mathrm{mg}$ of THC) was analysed in PD patients. It was shown that the therapy has no effect on dyskinesia, motor function, quality of life or sleep improvement (Carroll et al., 2004).

Another randomised, double-blind study, which analysed the effects of CBD on the improvement of motor function in PD patients (without mental disorders) and the quality of life, did not produce unequivocal results. The study included $21 \mathrm{PD}$ patients. The study participants were randomly assigned to 3 seven-person groups. Group I was given CBD at a dose of $75 \mathrm{mg} /$ day. Group II was given CBD at a dose of $300 \mathrm{mg} /$ day and Group III was given placebo. Throughout the study period ( 6 weeks), motor function and the quality of life were assessed. The results did not indicate any improvement in motor function, but some improvement in the quality of life in the CBD group (300 mg/day) was noted (Chagas et al., 2014).

In a review of studies covering both clinical and pre-clinical trials, Crippa et al. presented the analysis of data on the use of CBD in PD patients and data from preclinical trials. Of four randomised controlled clinical trials aimed at determining the effect of $\mathrm{CB} 1$ receptor agonists/antagonists on the mitigation of motor disturbances in PD patients, the reduction in L-DOPA-induced dyskinesia was found in one case only. A positive effect on non-motor symptoms was demonstrated. Due to the shortness and small-scale character of the studies, their reliability is limited (Crippa et al., 2019).

There are several important factors that may determine the success of cannabinoid therapy in PD, i.e. stage of disease and the use of L-DOPA. However, no serious adverse events were reported during CBD use. The observed adverse effects included mainly hypotension, dizziness, visual hallucinations and drowsiness. 


\section{Summary}

Cannabinoids are biologically active compounds extracted from cannabis. They differ in structure, properties and mechanism of action. TCH and CBD are their main representatives. THC is a psychoactive compound which shows greater affinity for cannabinoid receptors. Endocannabinoid CB1 and CB2 receptors are part of the endocannabinoid system which takes part in the proper functioning of the body and influences the internal homeostasis. CB1 is mainly responsible for proper nervous transmission while CB2 plays a key role in regulating the inflammatory response of the body.

The therapeutic potential of cannabis (Cannabis indica) has been known for thousands of years, but its use is controversial because of its psychotic effects, mainly caused by THC contained in it. For this reason, cannabis is thought to be addictive and produce narcotic effects. As a result, many countries prohibit the use, possession and cultivation of cannabis.

The analysis of clinical trials on the effect of cannabis-based preparations, mainly the mixture of THC and CBD, on alleviating the symptoms of epilepsy, indicates their potential therapeutic effect in reducing the frequency of seizures in children with drug-resistant epilepsy.
The most positive results were obtained in children with Lennox-Gastaut syndrome or Davet syndrome.

Literature review covering preclinical and clinical studies provides insufficient evidence of the efficacy of cannabis preparations in alleviation of symptoms in MS patients. However, some patients report health improvement due to the reduction of pain and spasticity. Therefore, the European Medicines Agency (EMA) registered Nabiximols as a preparation that can be used as an addition to the treatment of spasticity or pain if standard pharmacological treatment is ineffective.

There are few references to the impact of medical cannabis on alleviating the symptoms of Parkinson's disease. Most studies are limited to the preclinical phase. There are still few clinical trials and the results do not provide sufficient evidence of the validity of medical cannabis use.

The lack of clear clinical evidence of its effectiveness is the main cause of restriction on the use of medical cannabis in the treatment of diseases. It should also be emphasised that cannabinoids can significantly alter the concentrations of other drugs and interact with them in a way unknown so far. Also, patients should be informed of the possibility of adverse reactions, both already known and previously unreported.

\section{Wstęp}

Konopie to rośliny okrytonasienne z rodziny konopiowatych, jednoroczne. W amerykańskiej farmakopei konopie są definiowane jako wysuszone kwiatostany żeńskie pozbawione grubszych łodyg oraz dużych liści, przy czym zawartość owoców nie przekracza 10 procent. Wyróżnia się trzy gatunki konopi: konopie włókniste (Cannabis sativa L.), konopie indyjskie (Cannabis indica L.) oraz konopie dzikie (Cannabis ruderalis). Różnice między tymi gatunkami nie wynikają z budowy morfologicznej roślin, lecz są spowodowane wywoływanym przez nie odmiennym efektem psychotropowym. Konopie są powszechnie wykorzystywane w celach medycznych, kosmetycznych oraz spożywczych. Wpływają one pozytywnie na nastrój, wywołując uczucie radości i euforii, jednak ze względu na ich potencjalne właściwości uzależniające i zagrożenie związane z możliwością wywoły wania agresji u stosujących je osób w wielu krajach wprowadzono zakazy bądź ograniczenia w ich stosowaniu. Dopiero w ostatnich latach zaczęto badać tę grupę związków pod kątem wykorzystania w różnych jednostkach chorobowych (Vetulani i Mazurek, 2016).

\section{Przegląd piśmiennictwa}

\section{Historia rozwoju konopi}

Konopie są jedną z najstarszych uprawianych przez człowieka roślin. Gatunek konopi indyjskich znany był już 4 tysiące lat p.n.e. w Chinach, gdzie wykorzystywano go do produkcji lin, papieru, tekstyliów. Owoce tych roślin stanowiły natomiast pożywienie. Konopiom przypisywano właściwości przeciwbólowe, przeciwreumatyczne, stosowano jako środki przeciw zaparciom, malarii oraz w schorzeniach układu rozrodczego (Touwn, 1981).

Większe znaczenie konopie zyskały w Indiach. Mogło to być spowodowane związkiem między religią a rośliną, której przypisywano świętą rolę, uznawano ją za źródła szczęścia, radości i wolności. Uważano, iż wykazuje ona działanie: przeciwbólowe, uspokajające przeciwdrgawkowe, przeciwpasożytnicze, znieczulające, pobudzające apetyt, przeciwzapalne, przeciwskurczowe, moczopędne, przeciwkaszlowe i wykrztuśne. Konopie stosowano w leczeniu padaczki i wścieklizny, jako antybiotyk w różnego rodzaju infekcjach skóry, w gruźlicy, w problemach trawiennych, w zakażeniach układu oddechowego (Mathre, 1997; Zuardi, 2006). 
W Europie zachowane ślady archeologiczne wskazują na uprawę konopi w okresie poprzedzającym naszą erę. Popularyzację ich jako środków leczniczych zapoczątkował irlandzki lekarz William B. O’Shaughnessy, który bazując na wiedzy zdobytej podczas swoich podróży, zajął się badaniem tych roślin, oceniając ich działanie u zwierząt i ludzi. Na podstawie swoich odkryć napisał książkę, która stała się podstawowym źródłem wiedzy o konopiach, co zachęciło innych lekarzy i naukowców do kontynuowania jego badań. W połowie XIX wieku potencjał psychoaktywny konopi dokładnie opisał Jacques-Joseph Moreau, francuski psychiatra, który badał ich działanie na sobie i pacjentach szpitala psychiatrycznego (Russo, 2001). Stopniowo zaczęto sporządzać oraz sprzedawać różnego rodzaju preparaty i ekstrakty z konopi. Na początku XX wieku ich właściwości terapeutyczne opisali Charles E. de M. Sajous oraz Louis T. de M. Sajous w książce Sajous's Analytic Cyclopedia of Practical Medicine, która stanowiła rodzaj encyklopedii z zakresu medycyny praktycznej.

W pierwszych dziesięcioleciach XX wieku stosowanie konopi stawało się coraz rzadsze, co mogło być spowodowane zwiększeniem produkcji nowoczesnych leków, opracowanych w celu leczenia konkretnych schorzeń. Dodatkowo pojawiło się wiele ograniczeń prawnych ze względu na potencjał narkotyczny konopi. Ponowne zainteresowanie konopiami pod koniec XX wieku wynikało z rozszerzonych możliwości analizy ich składu chemicznego oraz zwiększenia czystości wyizolowanych z niej substancji aktywnych (Mikuriya, 1969).

\section{Konopie przemysłowe}

W Polsce zgodnie z Ustawą z dnia 29 lipca 2005 roku o przeciwdziałaniu narkomanii za konopie przemysłowe uznaje się konopie włókniste $\mathrm{z}$ gatunku Cannabis sativa L., w których zawartość THC w kwiatowych lub owocujących wierzchołkach tej jednopiennej rośliny (bez usunięcia żywicy) nie przekracza 0,2\% w przeliczeniu na suchą masę (Ustawa z dnia 29 lipca 2005 r. o przeciwdziałaniu narkomanii). Takie konopie są wykorzystywane między innymi do produkcji włókien. Popularność ich uprawy wynika z odporności na szkodniki i suszę oraz mniejszego zapotrzebowania na wodę niż np. w przypadku bawełny. W przemyśle spożywczym stosuje się olej konopny, który bogaty jest w niezbędne składniki odżywcze (Siudem i wsp., 2015). W zależności od warunków uprawy roślin, olej taki charakteryzuje się zmienną wartością CBD (Leizer i wsp., 2000).

W przemyśle kosmetycznym olej konopny jest stosowany ze względu na swoje działanie nawilżające oraz antyseptyczne (Tennstedt i Saint-Remy, 2011). Uważa się, że ma potencjał jako środek terapeutyczny w leczeniu trądziku pospolitego (Oláh i wsp., 2014). W przemyśle budowlanym konopie wykorzystywane są w celu pozyskania materiałów stosowanych do ocieplania domów, izolacji, zapraw murarskich. Dodatkowo, z oleju konopnego pozyskiwany jest olej napędowy i biomasa opałowa, czy też bioplastiki o dużej wytrzymałości (Vetulani i Mazurek, 2016; Frassinettia i wsp., 2018; Kilpeläinenb i wsp., 2019).

\section{Kannabinoidy}

Kannabinoidy są to podstawowe związki aktywne, które oddziałują na receptory kannabinoidowe. Dzielą się na 3 podgrupy: kannabinoidy pochodzenia roślinnego - fitokannabinoidy, kannabinoidy wytwarzane przez organizmy zwierzęce oraz człowieka - endokannabinoidy oraz kannabinoidy syntetyczne.

Fitokannabinoidy są związkami terpenowymi izolowanymi z żywicy. Zalicza się do nich około 60 substancji. Syntetyzowane są one głównie w żeńskich kwiatostanach konopi; najwięcej ich jest w niezapylonych kwiatach. Są obecne w materiale roślinnym, głównie w postaci nieaktywnych kwasów karboksylowych, np. tetrahydrokannabinolowego (THCA-A) i kannabidiolowego (CBDA), które pod wpływem wysokiej temperatury ulegają dekarboksylacji do aktywnych postaci: kolejno do trans- $\Delta^{9}$-tetrahydrokanabinolu (THC, rycina 1 ) oraz kannabidiolu (CBD, rycina 2).

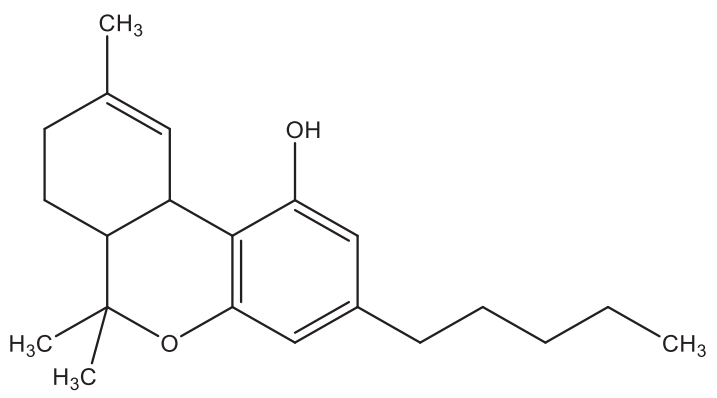

Rycina 1. $\Delta^{9}$-tetrahydrokanabinol (THC)

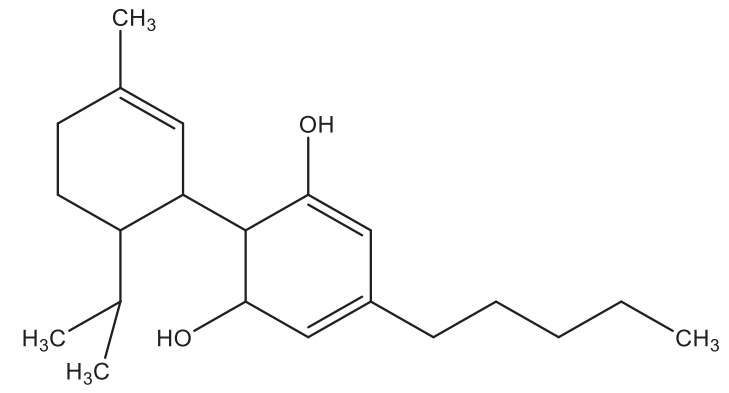

Rycina 2. Kannabidiol (CBD)

Tetrahydrokannabinol (THC) jest to związek, który został wyizolowany z Cannabis sativa. Jest to psychoaktywny, aromatyczny terpenoid, zawierający ugrupowanie fenolowe. THC odpowiada za potencjał narkotyczny konopi. Wywołuje uczucie euforii oraz wykazuje działanie przeciwwymiotne, przeciwbólowe, antyoksydacyjne 
oraz przeciwzapalne (Kaczmarczyk-Sedlak i wsp., 2017). THC jest rozpuszczalny w tłuszczach, dlatego po podaniu gromadzi się głównie w tkance tłuszczowej, płucach, wątrobie oraz śledzionie. Jego zawartość w konopiach różni się w zależności od warunków hodowli, wieku, modyfikacji genetycznych czy też typu tkanki rośliny. Wartości te mogą się wahać w szerokim zakresie od 0,001 do $10 \%$. Z tego względu w obrębie jednego gatunku wyróżnia się kilka odmian konopi (osobniki, u których stężenie THC wynosi poniżej 1\%, stosowane są przemyśle, natomiast te z wyższymi wartościami THC przeznaczone są do produkcji marihuany), (Gaoni i Mechoulam, 1964). Najwięcej THC znajduje się w kwiatostanach i żywicy, najmniej w liściach (Siudem i wsp., 2015; Silska, 2017; The Advisability and Feasibility of Developing USP Standards for Medical Cannabis: https://www. uspnf.com/sites/default/files/usp_pdf/EN/USPNF/uspnf-notices/usp_stim article_medical_cannabis.pdf).

Kannabidiol (CBD) jest związkiem pozbawionym potencjału narkotycznego. Uważany jest za najczęściej występujący fitokannabinoid. W porównaniu do THC wykazuje nieznaczne różnice w strukturze, jednakże różnice te powodują antagonistyczne działanie obu związków. Ma niższe powinowactwo do receptorów CB1 i wyższe do receptorów CB2 niż THC, dlatego bardziej wpływa na działanie układu odpornościowego niż nerwowego (Adams i wsp., 1940; Siudem i wsp., 2015).

\section{Endokannabinoidy}

Endokannabinoidy są grupą związków występujących w organizmach zwierząt, w tym również człowieka. Powstają one z prekursorów lipidowych, głównie długołańcuchowych kwasów tłuszczowych, np. kwasu arachidonowego. Jest to kwas wchodzący w skład fosfolipidów błon komórek nerwowych, co ma istotne znaczenie w funkcjonowaniu układu nerwowego. Endokannabinoidy nie są magazynowane $w$ organizmie (jak typowe neuroprzekaźniki), ale są wytwarzane w odpowiedzi na napływające jony wapnia i depolaryzację błony. Najbardziej znanymi i najlepiej opisanymi endokannabinoidami są anandamid (AEA) i 2arachidonoiloglicerol (2AG), które choć podobne strukturalnie do siebie, są syntetyzowane i degradowane przez różne szlaki enzymatyczne. Anandamid stymuluje receptory oraz kanały jonowe, natomiast 2arachidonoiloglicerol jest głównie neuromodulatorem. Ulegając hydrolizie pod wpływem odpowiednich enzymów, związki te indukują różne procesy komórkowe (Mauryaa i Velmurugan, 2018; Kaczmarczyk-Sedlak i wsp., 2017).

\section{Układ endokannabinoidowy}

Endokannabinoidy wraz z receptorami kannabinoidowymi i ich endogennymi ligandami, kompleksami enzymów oraz białkami regulującymi tworzą układ endokannabinoidowy (eCB). Endokannabinoidy wykazują odmiennie działanie na receptory. Ich agonistyczny wpływ umożliwia pobudzanie tego układu poprzez aktywację dwóch typów receptorów. W 1990 roku udało się zidentyfikować i sklonować pierwszy typ receptorów kannabinoidowych - CB1 (Gerard i wsp., 1991), następnie w 1993 roku zidentyfikowano oraz sklonowano drugi typ - CB2 (Munro i wsp., 1993). Receptory te występują w różnych miejscach w organizmie człowieka, gdzie pełnią określone funkcje $w$ procesach patofizjologicznych. Są one sprzężone $\mathrm{z}$ białkiem $\mathrm{G}$ oraz są modulatorami wydzielania neuroprzekaźników. Receptory kannabinoidowe 1 (CB1) znajdują się głównie na zakończeniach komórek nerwowych, pośrednicząc w uwalnianiu przekaźników, natomiast receptory CB2 mają działanie immunomodulujące i regulujące aktywność cytokin oraz migrację komórek odpornościowych. Dostrzegając w tym ogromny potencjał, zaczęto modyfikować ich działanie, aby uzyskać zamierzony efekt terapeutyczny.

Układ endokannabinoidowy jest bardzo złożony ze względu na wielofunkcyjność i często antagonistyczne działanie związków w jego obrębie. Już nieznaczne zaburzenia tego układu przyczyniają się do rozwoju stanów patologicznych obejmujących układ krążenia, ośrodkowy układ nerwowy, układ immunologiczny, układ oddechowy, pokarmowy oraz skórę. Znajomość funkcjonowania receptorów kannabinoidowych oraz ich interakcji z neuroprzekaźnikami stwarza możliwość modyfikacji procesów fizjologicznych. Ponadto zastosowanie syntetycznych antagonistów tych receptorów w sytuacji nadmiernego pobudzenia układu endokannabinoidowego pozwala na przywrócenie homeostazy wewnątrz organizmu (Pertwe, 2006; Scholten, 2006; Silska, 2017).

\section{Marihuana}

Marihuana jest to produkt pozyskiwany z odmian konopi charakteryzujących się wysoką zawartością THC (0,5-9\%). Ze względu na znaczne stężenie tego związku, zgodnie z ustawodawstwem, produkt ten został uznany za zdolny do wywołania reakcji psychotycznych. Marihuana pozyskiwana jest z liści z kwitnącymi i owocującymi górnymi pędami dwupiennej odmiany, głównie z niezapylonych osobników żeńskich. Do jej otrzymania nie potrzeba żadnej obróbki, najczęściej stanowią ją wysuszone fragmenty rośliny, które są palone podobnie jak papierosy albo sporządza się z nich wywary. Efekt działania marihuany zależy od zastosowanej dawki, sposobu jej podania, częstości stosowania, stanu psychicznego używającej je osoby. Najpopularniejszymi formami przyjmowania marihuany są doustna i wziewna. Droga wziewna jest to najskuteczniejsza metoda, dająca efekt natychmiastowy (już po 5 minutach), ponieważ marihuana przedostaje się do organizmu w niezmienionej formie, a następnie przez płuca przenika bezpośrednio 
do krwiobiegu. Efekt uzyskany podczas przyjęcia marihuany drogą doustną pojawia się później, po ok. 30-90 minutach. Najpopularniejszą formą stosowania marihuany jest jej palenie (podobnie jak palenie tytoniu). Jest to niebezpieczna forma stosowania - ze względu na powstające $\mathrm{w}$ trakcie spalania szkodliwe związki. Substancja czynna, THC, zawarta w marihuanie dociera do płuc w ilości $20-70 \%$, natomiast do mózgu $5-24 \%$. Regularne wypalanie 3-5 skrętów z marihuaną dziennie wywołuje tolerancję, natomiast sporadyczne palenie spowoduje efekt już po przeniknięciu 2-3 mg THC. Szacowana dawka THC, która wywołuje zgon człowieka, waha się między $15 \mathrm{~g}$ a $70 \mathrm{~g}$.

Marihuanę określa się jako „medyczną” lub „rekreacyjną". Różnią się one celem stosowania, co ma podłoże prawne. Za „medyczną marihuanę" można uznać substancję pozyskaną z marihuany do celów medycznych, z której otrzymywane są standaryzowane produkty i których uprawa jest ściśle kontrolowana. Termin „,marihuana rekreacyjna" odnosi się głównie do uzyskiwania efektu relaksacji na skutek jej użytkowania, któremu może towarzyszyć efekt medyczny (Hall i Degenhardt, 2009; Vetulani, 2014).

\section{Działania niepożądane stosowania marihuany}

Negatywne skutki stosowania marihuany versus jej pozytywne działanie są tematem wielu badań i dyskusji. Nie bez powodu zabronione jest stosowanie marihuany w celach rekreacyjnych. Wynika to z potencjału narkotycznego, jaki wykazuje THC. Stosowanie marihuany, szczególnie popularne wśród młodych ludzi, ma na celu osiągnięcie odprężenia i uczucia euforii. Jednak mogą również wystąpić efekty niepożądane, takie jak: zaburzenia świadomości i percepcji, urojenia, stany lękowe, zaburzenia koncentracji oraz opóźnione reakcje, które stwarzają ryzyko wypadków. Dodatkowo paleniu marihuany często towarzyszy picie alkoholu oraz zażywanie takich narkotyków, jak kokaina czy amfetamina, co również prowadzi do wzmocnienia większości działań niepożądanych. Wyniki przeprowadzonych badań wskazują na negatywny wpływ marihuany na układ krążenia. U osób ją stosujących może dojść do tachykardii oraz zmian ciśnienia krwi, co z kolei może być przyczyną np. zawrotów głowy. Marihuana wykazuje również negatywny wpływ na układ oddechowy poprzez odkładanie się substancji smolistych podczas jej palenia, co wpływa na wydolność płuc, może doprowadzić do uszkodzenia oskrzeli lub zwiększyć prawdopodobieństwo wystąpienia raka układu oddechowego. Wpływa również na masę urodzeniową noworodków u matek stosujących ją podczas ciąży - przyczynia się do małej masy urodzeniowej dzieci. Długotrwałe stosowanie marihuany może doprowadzić do zaburzeń somatycznych oraz psychozy. U osób stosujących duże dawki marihuany po jej odstawieniu mogą wystąpić objawy odstawienne (niepokój, nerwowość, bezsenność). W porównaniu z alkoholem nie wywołuje tak dużego efektu psychotycznego, ale nie znaczy to, że jej użytkowanie jest bezpieczne i pozbawione konsekwencji zdrowotnych (Dąbrowska i wsp., 2012; Wojnar, 2018).

\section{Legalizacja marihuany}

Legalizacja marihuany była jedną z najbardziej kontrowersyjnych kwestii w dziedzinie zdrowia publicznego. Wieloletnie zakazy stosowania, a w konsekwencji nielegalne użytkowanie wymusiły w wielu państwach zaktualizowanie polityki dotyczącej legalizacji marihuany. W Stanach Zjednoczonych Ameryki Północnej medyczne zastosowanie marihuany jest legalne w 33 stanach, natomiast rekreacyjne w 11 stanach (Collingwood i wsp., 2018; State Medical Marijuana Laws, National Conference of State Legislatures, 2018). W większości krajów Unii Europejskiej posiadanie marihuany w celach rekreacyjnych jest zabronione i uznawane za przestępstwo. Obecnie za zgodą odpowiednich organów państwowych coraz więcej państw zezwala na jej stosowanie, ale tylko i wyłącznie w celach medycznych. Jedynymi państwami UE, w których posiadanie marihuany rekreacyjnej na własny użytek jest dozwolone, w ilościach ściśle określonych w ustawodawstwie, są: Belgia, Czechy, Holandia i Hiszpania. W Holandii są także specjalne miejsca nazywane coffeeshopami, gdzie można ją legalnie zakupić (Bifulco i Pisanti, 2015). Urugwaj jest pierwszym państwem na świecie, które - w 2017 roku - zalegalizowało marihuanę, jej stosowanie, uprawę oraz handel. Wprowadzona ustawa określa maksymalną ilość, jaką można nabyć w aptekach (40 gramów miesięcznie) oraz wymaga pełnoletności od jej posiadacza (legalność marihuany na świecie: https://www.cannabisnews.pl/legalnoscmarihuany-na-swiecie/).

Polska jest krajem, w którym posiadanie marihuany w celach rekreacyjnych jest nielegalne i uważane za przestępstwo. Zgodnie z Ustawą wydaną przez Sejm w 2017 roku możliwe jest stosowanie marihuany wyłącznie w celach terapeutycznych (Ustawa z dnia 7 lipca 2017 r. o zmianie ustawy o przeciwdziałaniu narkomanii oraz ustawy o refundacji leków, środków spożywczych specjalnego przeznaczenia żywieniowego oraz wyrobów medycznych). Receptę na nią może wystawić każdy lekarz, jednak nie jest ona refundowana.

\section{Analiza danych doświadczalnych i klinicznych określających wpływ medycznej marihuany w wybranych schorzeniach}

Stosowanie marihuany i jej pochodnych jako środków leczniczych budzi wiele kontrowersji. W społeczeństwie występują dwie odmienne opinie na ich temat: część osób uważa je za środki narkotyczne i domaga się restrykcyjnych zasad dotyczących ich stosowania, natomiast część 
osób przypisuje im właściwości terapeutyczne i oczekuje ich legalizacji.

Do chwili obecnej przeprowadzono szereg badań doświadczalnych oraz badań klinicznych z wykorzystaniem marihuany, mających na celu potwierdzenie skuteczności i bezpieczeństwa jej stosowania. Głównymi związkami aktywnymi, którym przypisuje się efektywność działania medycznej marihuany, są CBD, rzadziej THC. Preparaty powstałe na ich bazie są preparatami jednoskładnikowymi zawierającymi wyłącznie CBD lub w formie mieszanin CBD/THC w proporcji 1:1. W Polsce jest aktualnie zarejestrowanych pięć surowców farmaceutycznych z medycznej marihuany (https://mgr.farm/aktualnosci/ juz-piec-surowcow-farmaceutycznych-z-medycznej-marihuany-zarejestrowanych-w-polsce/) oraz tylko jeden preparat kannabinoidowy - Sativex (nabiksimol), będący mieszaniną THC oraz CBD do leczenia wspomagającego napięcia spastycznego $u$ chorych ze stwardnieniem rozsianym. O tym, czy preparat może być wprowadzony jako dodatek do standardowej farmakoterapii, decyduje lekarz i to on ponosi pełną odpowiedzialność za potencjalne ryzyko zastosowania (Bergamaschi i wsp., 2011; Wachowiak i wsp., 2016).

Analiza wyników przeprowadzonych badań wskazuje na możliwość zastosowania marihuany w leczeniu lub łagodzeniu objawów wielu chorób, takich jak: padaczka, stwardnienie rozsiane, choroba Alzheimera, choroba Parkinsona, jaskra, bóle reumatoidalne stawów, nowotwory, choroby przewodu pokarmowego, AIDS, zaburzenia metabolizmu, astma i wiele innych (Motyka i Marcinkowski, 2014).

\section{Padaczka}

Jedną z najczęściej występujących chorób neurologicznych jest padaczka. Charakteryzuje się występowaniem napadów padaczkowych, które wynikają z zaburzeń czynnościowych mózgu i jest spowodowana nadmiernymi wyładowaniami bioelektrycznymi neuronów. Leczenie padaczki opiera się na farmakoterapii stosowanej przez cały okres trwania choroby. Gdy stosowanie 2-3 leków nie przynosi efektów, jako alternatywną metodę leczenia można wykorzystać medyczną marihuanę stosowaną w postaci doustnej (Rozenek i Owczarek, 2010).

W 2015 roku Press i wsp. przedstawili wyniki ankiet przeprowadzonych wśród rodziców 75 dzieci z padaczką. W ankietach tych pytano między innymi o typ oraz częstość napadów. Dzieci leczone były codziennie doustnymi preparatami z konopi - jako dodatek do standardowej farmakoterapii. Czas obserwacji wynosił 1-4 miesiące. Wśród 75 badanych dzieci rodzice 43 (57\%) z nich zgłosili zmniejszenie częstości napadów. Dodatkowo według opiekunów poprawiła się koncentracja (33\%) oraz mowa (11\%). Na podstawie otrzymanych wyników ankiet autorzy zasugerowali, że wprowadzenie doustnych preparatów z konopi u dzieci z padaczką spowodowało poprawę stanu ich zdrowia, jednak należy pamiętać, że jest to tylko subiektywna ocena rodziców chorych dzieci, bez przeprowadzenia rzetelnych badań klinicznych (Press i wsp., 2015).

Porter i Jacobson w swoim badaniu analizowali stosowanie preparatów $\mathrm{z}$ konopi wzbogaconych $\mathrm{w}$ kannabidiol u 19 dzieci z padaczką lekooporną (dzieci w wieku 2-16 lat), u których wcześniej stosowane leki przeciwpadaczkowe nie przyniosły oczekiwanych efektów. Dzieciom podawano preparaty z CBD (0,5 mg/kg/dobę do $28,6 \mathrm{mg} / \mathrm{kg} /$ dobę) przez okres od 1 do nawet 12 miesięcy. Wśród rodziców małych pacjentów przeprowadzono ankietę zawierającą 24 pytania dotyczące m.in. czynników klinicznych, w tym rodzaju napadów oraz efektów stosowania CBD. Szesnaścioro (84\%) z 19 rodziców zgłosiło zmniejszenie częstości napadów u swoich dzieci. U dwójki dzieci (11\%) nastąpił całkowity zanik napadów, u 8 (42\%) nastąpiło ponad 80-proc. zmniejszenie częstości napadów, a u 6 (32\%) zmniejszenie napadów o $25-60 \%$. W opinii rodziców innym korzystnym efektem wynikającym ze stosowania tego preparatu była poprawa jakości życia dzieci ze względu na redukcję napadów, natomiast działania niepożądane terapii obejmowały senność oraz zmęczenie. Autorzy stwierdzili, że wyniki tego badania są dowodem na skuteczność CBD w leczeniu dzieci z padaczką lekooporną, jednak takie dane będące tylko oceną rodziców o bardzo zróżnicowanym okresie obserwacji nie są wystarczające do potwierdzenie skuteczności (Porter i Jacobson, 2013).

Hussain i wsp. w 2017 roku przedstawili wyniki badania, w którym analizowali efekty stosowania kannabidiolu (CBD) w dawce $4,3 \mathrm{mg} / \mathrm{kg} /$ dobę u dzieci z zespołem Lennoxa-Gastauta lub zespołem Westa. Do badania włączono 117 dzieci w różnym wieku. Okres obserwacji wynosił średnio 7 miesięcy. Wśród rodziców dzieci przeprowadzono ankietę zawierającą serię pytań dotyczących charakterystyki zespołu padaczkowego, klasyfikacji, podstawowej etiologii, skuteczności farmakoterapii, częstości występowania działań niepożądanych przed i po ekspozycji na CBD oraz czasu stosowania CBD. Ze 117 rodziców 100 (85\%) zgłosiło zmniejszenie częstotliwości napadów, natomiast 16 (10\%) - całkowity zanik napadów. Jako działanie niepożądane wymieniano zwiększony apetyt, natomiast dodatkowymi korzyściami u ponad $50 \%$ pacjentów była poprawa snu, nastroju oraz koncentracji. Wyniki tego badania wskazywały na skuteczność CBD w terapii lekoopornej padaczki u dzieci, jednak wymagane jest przeprowadzenie badań klinicznych, dostarczających obiektywnych dowodów potwierdzających ten efekt w tak zróżnicowanej wiekowo grupie pacjentów (Hussain i wsp., 2015).

Thiele i wsp. w randomizowanym, podwójnie zaślepionym, kontrolowanym placebo badaniu analizowali skuteczność stosowania preparatu kannabidiolu (CBD) u osób z zespołem Lennoxa-Gastauta. Badanie zostało przeprowadzone w 24 ośrodkach klinicznych w USA, 
Holandii i w Polsce. Uczestnikami badania było 171 pacjentów w przedziale wiekowym 2-55 lat, który musieli spełnić następujące kryteria: więcej niż jeden typ napadu padaczkowego w okresie dłuższym niż pół roku, 2 napady atoniczne tygodniowo podczas 4-tygodniowego okresu początkowego choroby, brak skuteczności stosowania co najmniej 2 leków. Pacjenci zostali losowo przydzieleni do dwóch grup: część otrzymywała $20 \mathrm{mg} /$ $\mathrm{kg} /$ dobę doustnego preparatu CBD przez okres 14 tygodni, pozostali placebo. U osób w grupie badanej zaobserwowano zmniejszenie miesięcznej liczby napadów o średnio 44\% (u 3 osób w grupie CBD nastąpiła całkowita remisja), natomiast u osób z grupy placebo o $22 \%$. U 86 pacjentów w grupie CBD i 59 (69\%) z 85 pacjentów w grupie placebo wystąpiły objawy niepożądane takie jak: senność, biegunka, gorączka, zmniejszenie apetytu i wymioty. Wyniki badania sugerowały skuteczność CBD w leczeniu pacjentów z napadami padaczkowymi związanymi z zespołem Lennoxa-Gastauta, ale ze względu na szeroką rozbieżność wiekową wiarygodność takich wyników i możliwość wyciągnięcia jednoznacznych wniosków są znacznie ograniczone (Thiele i wsp., 2018).

Devinsky i wsp. w randomizowanym badaniu analizowali skutki stosowania kannabidiolu. Do badania włączono 214 chorych w wieku 1-30 lat z ciężką, lekooporną postacią padaczki. Badanie zostało przeprowadzone w 11 ośrodkach w USA w ciągu 12 miesięcy. Uczestnicy badania otrzymywali CBD początkowo w dawce $2-5 \mathrm{mg} / \mathrm{kg} /$ dobę. Dawkę tę stopniowo zwiększano do maksymalnej dawki $25 \mathrm{mg} / \mathrm{kg}$ lub $50 \mathrm{mg} / \mathrm{kg}$ na dobę. 162 pacjentów (76\%) spośród 214 badanych po przyjęciu pierwszej dawki CBD włączono do analizy bezpieczeństwa i tolerancji preparatu, a 137 pacjentów (64\%) włączono do analizy skuteczności. W grupie osób, u których badano bezpieczeństwo CBD 33 pacjentów (20\%) miało zespół Draveta, a 31 (19\%) zespół Lennoxa-Gastauta. Pozostali pacjenci mieli ciężkie postaci padaczki o różnej etiologii. Działania niepożądane zgłoszono u 128 ze 162 pacjentów (79\%) uczestniczących w badaniu bezpieczeństwa stosowania preparatu CBD. Zdarzenia niepożądane zgłaszane u ponad 10\% pacjentów obejmowały: senność, zmniejszenie apetytu, biegunkę, zmęczenie i drgawki. Pięciu pacjentów (3\%) przerwało leczenie z powodu zdarzenia niepożądanego. Poważne zdarzenia niepożądane odnotowano u 48 pacjentów (30\%), w tym jeden zgon - uważany za niezwiązany z badanym lekiem. U 20 pacjentów (12\%) wystąpiły ciężkie działania niepożądane. Średnia redukcja miesięcznej liczby napadów wyniosła 36,5\%. Wyniki tych badań wskazywały na możliwość zmniejszenia częstotliwości napadów u osób z padaczką lekooporną stosujących CBD, ale konieczne jest przeprowadzenie kontrolowanych i randomizowanych badań (Devinsky i wsp., 2016).

W 2017 roku Devinsky przeprowadził kolejne badanie. Do badania włączono 120 osób w wieku 2-18 lat z lekoopornym zespołem Draveta. Badanie prowadzono metodą podwójnie ślepej próby kontrolowanej grupą otrzymującą placebo. Uczestnicy badania otrzymali doustnie roztwór CBD w dawce $20 \mathrm{mg} / \mathrm{kg}$.m.c./dobę jako dodatkowy element terapii lub placebo. Badanie objęło okres 14 tygodni. Zaobserwowano zmniejszenie częstości napadów padaczkowych z około 12 do 6 w miesiącu $\mathrm{w}$ grupie stosującej CBD, natomiast $\mathrm{w}$ grupie placebo $\mathrm{z} 12$ do 11. Wśród pacjentów, u których wystąpiła co najmniej 50-proc. redukcja częstości napadów, $43 \%$ stosowało CBD, $27 \%$ przyjmowało placebo. Ogólny stan pacjenta poprawił się u $62 \%$ osób w grupie CBD oraz u $34 \%$ osób w grupie placebo. Częstość napadów była znacznie zmniejszona w przypadku stosowania CBD, natomiast bez zmian w grupie osób z napadami bezdrgawkowymi. U 5\% pacjentów z grupy CBD nastąpiła całkowita remisja. Działania niepożądane częściej występowały w grupie CBD niż w grupie placebo i obejmowały: biegunkę, wymioty, zmęczenie, gorączkę, senność i nieprawidłowe wyniki testów czynnościowych wątroby. Odnotowano również więcej przypadków przerwania terapii w grupie CBD. Wyniki badania potwierdziły zmniejszenie częstości napadów padaczkowych u dzieci przyjmujących CBD w szerokim przedziale wiekowym, jednakże stosowanie leku często wiązało się z wystąpieniem działań niepożądanych (Devinsky i wsp., 2017).

Najnowsze zalecenia dotyczące leczenia napadów padaczkowych u dorosłych oparte na wytycznych opublikowanych przez Międzynarodową Ligę Przeciwpadaczkową i Amerykańską Akademię Neurologii jak dotąd nie uwzględniły możliwości stosowania preparatów z konopi mimo wielu pozytywnych choć niejednoznacznych wyników badań naukowych. Wskazano jedynie na potencjalne zastosowanie preparatów na bazie CBD jako alternatywnej metody leczenia, gdy standardowa terapia jest nieskuteczna (Jędrzejczak i wsp., 2019).

Amerykańskie Towarzystwo Padaczkowe (American Epilepsy Society, AES), którego członkami są klinicyści oraz naukowcy, monitoruje wszystkie badania dotyczące leczenia padaczki medyczną marihuaną oraz stara się opracować bezpieczne i skuteczne zasady takiej terapii. Do niedawna pojawiały się jedynie doniesienia o skutecznym działaniu CBD w pojedynczych przypadkach padaczki. W ostatnim czasie ukazały się wyniki randomizowanych, kontrolowanych badań klinicznych z podwójnie ślepą próbą dotyczące stosowania wysoko oczyszczonego oraz o wysokim stężeniu CBD. Wyniki te wskazywały na umiarkowaną skuteczność CBD w leczeniu zespołu Lennoxa-Gastauta oraz zespołu Draveta. (AES, Position Statement on Cannabis as a Treatment for Patients with Epileptic Seizure, February 2019). AES przyczyniło się do zatwierdzenia przez Agencję Żywności i Leków (FDA) leku w formie doustnego roztworu kannabidiolu - Epidiolexu, dostępnego wyłącznie na receptę. Jednakże w dalszym ciągu podkreśla się konieczność zaplanowania i przeprowadzenia wieloośrodkowych, 
kontrolowanych, poprawnych metodologicznie badań dla wszelkich produktów na bazie konopi. Wyniki tych badań mogłyby pomóc w ustaleniu dawkowania, poznaniu działań niepożądanych i potencjalnych interakcji $\mathrm{z}$ innymi lekami (Giancaspro i wsp., https://www.uspnf.com/sites/default/files/usp_pdf/EN/USPNF/usp-nfnotices/usp_stim_article_medical_cannabis.pdf).

Interakcje pomiędzy lekami przeciwpadaczkowymi (LPP) a preparatami CBD są jednym z ważnych aspektów, na które należy zwrócić uwagę przed podjęciem decyzji o wprowadzeniu CBD do terapii. Gaston i wsp. analizowali możliwe interakcje między CBD a lekami przeciwpadaczkowymi. Do badania włączono 39 dorosłych oraz 42 dzieci z padaczką lekooporną, którzy co najmniej przez miesiąc przed rozpoczęciem badania regularnie przyjmowali leki. Dawka początkowa CBD wynosiła $5 \mathrm{mg} / \mathrm{kg} /$ dobę i była zwiększana co 2 tygodnie o $5 \mathrm{mg} / \mathrm{kg} /$ dobę do maksymalnej dawki $50 \mathrm{mg} / \mathrm{kg} /$ dobę. Dawki LPP były natomiast ustalane w zależności od wystąpienia niepożądanych objawów lub przekroczenia ich tolerowanego poziomu w surowicy krwi. Uzyskane przez autorów wyniki nie pozwoliły na ustalenie jednoznacznego wniosku co do interakcji pomiędzy LPP a preparatami z konopi. Prawie wszystkie odnotowane średnie zmiany stężenia LPP mieściły się w akceptowanym zakresie terapeutycznym. Zaobserwowano zwiększone wartości dla AST/ALT u badanych stosujących walproinian, co wskazywało na konieczność monitorowania nie tylko poziomów LPP w surowicy, ale także wykonywanie testów wątrobowych podczas przyjmowania CBD (Gaston i wsp., 2017).

Wyniki niektórych badań wykazały, że stosowanie dużych dawek CBD, nawet do $1500 \mathrm{mg} /$ dobę, jest dobrze tolerowane $\mathrm{u}$ ludzi. $\mathrm{Z}$ kolei w innych badaniach wyniki były całkowicie przeciwne - zaobserwowano wystąpienie działań niepożądanych, takich jak: hamowanie metabolizmu leków, cytotoksyczność, zmniejszenie aktywności receptorów. Takie rozbieżności w wynikach badań świadczą o konieczności ustalenia dawki optymalnej, bezpiecznej dla ludzi (Bergamaschi i wsp., 2011).

Mechanizm działania medycznej marihuany w padaczce nie jest do końca znany. Dotychczas udowodniono jej efektywność jako modulatora wewnątrzkomórkowego stężenia jonów wapnia. Homeostaza jonów wapnia oraz aktywność metaboliczna to dwa najważniejsze czynniki, które warunkują żywotność neuronów, zależnie od funkcjonowania mitochondrium. Nawet niewielkie deficyty czynności mitochondriów mogą nieść negatywne skutki, ostatecznie doprowadzające do procesów zwyrodnieniowych. Uważa się, że regulacja homeostazy jonów wapnia za pośrednictwem CBD jest dwukierunkowa, w zależności od pobudliwości komórek. W warunkach fizjologicznych powoduje zwiększenie stężenia jonów wapnia wewnątrz komórek, natomiast w warunkach wysokiej pobudliwości zmniejsza jego stężenie. Takie antagonistyczne działanie CBD pozwala na regulację homeostazy wapniowej i zapewnienie prawidłowej pobudliwości komórkowej, zapobiegając nieprawidłowym wyładowaniom bioelektrycznym. Wykazano również, że endokannabinoidy odgrywają ważną rolę w kontroli transmisji synaptycznej i regulacji szybkości migracji neuronów. W ośrodkowym układzie nerwowym receptory CB1 ulegają ekspresji presynaptycznie, zarówno na interneuronach glutaminianergicznych, jak i GABA-ergicznych, a ich aktywacja powoduje zahamowanie transmisji synaptycznej, w tym uwalnianie glutaminianu. Sugeruje się także wpływ CBD jako związku hamującego wychwyt zwrotny serotoniny oraz antagonisty receptora sprzężonego $\mathrm{z}$ białkiem GPR55 (Foldy, 2006; Ryan i wsp., 2009; Perucca, 2017).

\section{Stwardnienie rozsiane}

Stwardnienie rozsiane (sclerosis multiplex, SM) jest przewlekłą, demielinizacyjną zapalną chorobą ośrodkowego układu nerwowego. Zastosowanie medycznej marihuany jest jedną z możliwości łagodzenia objawów tej choroby głównie bólu związanego ze spastycznością - oraz reakcją zapalną (Świątek, 2016).

Terapeutyczne działania medycznej marihuany wynika prawdopodobnie $\mathrm{z}$ funkcjonalnej roli receptorów kannabinoidowych (CB1 oraz CB2) stanowiących jeden z elementów układu endokannabinoidowego. Receptor CB1 pośredniczy w przekaźnictwie sygnałów nerwowych, natomiast receptor CB2 bierze udział w procesach immunomodulujących, regulując aktywność komórek układu odpornościowego.

Wyniki badań przeprowadzonych na szczurach wskazują na łagodzenie drżenia oraz spastyczności pod wpływem THC oraz agonistów receptorów CB1 i CB2. W badaniach klinicznych z kolei analizowano rolę receptora CB1, ponieważ wpływając na niego, można hamować proces neurodegeneracyjny w SM. Receptor CB2 jako modulator ekspresji limfocytów oraz makrofagów prawdopodobnie ma zdolność regulacji procesu zapalnego, który w stwardnieniu rozsianym jest główną przyczyną demielinizacji i zaburzenia przewodnictwa sygnałów między neuronami. Istotne znaczenie w terapii SM przypisuje się endokannabinoidom: 2-AG oraz AEA, będącym bioaktywnymi lipidami regulującymi funkcjonowanie OUN. Wprowadzenie inhibitora lipazy monoacyloglicerolowej (MAGL), którego działanie polegające na hamowaniu degradacji endokannabinoidów zapobiega degeneracji komórek nerwowych, zapewnia ochronę oligodendrocytów, co pozwala zachować integralność mieliny i prawidłowe przekaźnictwo sygnałów nerwowych (Baker i wsp., 2001; Bernal-Chico i wsp., 2015; Przybek i wsp., 2017; Chiurchiùa i wsp., 2018).

Wade i wsp. w randomizowanym, kontrolowanym placebo, podwójnie zaślepionym badaniu analizowali wpływ stosowania preparatu na bazie konopi na łagodzenie objawów SM. Badanie przeprowadzono 
w 3 ośrodkach w Wielkiej Brytanii. Do badania włączono 160 pacjentów z potwierdzonym SM o różnym przebiegu, którzy mieli co najmniej jeden z następujących objawów: spastyczność, skurcze, ból, drżenie, problemy z pęcherzem oraz przyjmowali regularnie leki i nie mieli rzutu choroby przez ostatnie 4 tygodnie. Przez okres sześciu tygodni połowie chorych podawano doustny preparat na bazie konopi - nabiksimol w dawkach 2,5-120 mg/ dobę, natomiast pozostałe osoby otrzymywały placebo. Pacjenci zapisywali wyniki wizualnej skali analogowej (VAS) dla najbardziej uciążliwego objawu oraz ocenę innych objawów, niepełnosprawności, zaburzeń funkcji poznawczych, nastroju, snu oraz stopnia zmęczenia. Wyniki badania wskazywały na zmniejszenie częstości występowania najbardziej uporczywego z objawów (głównie spastyczności) częściej u osób stosujących preparat kannabinoidowy niż w grupie placebo. Nie stwierdzono znaczącego wpływu na funkcje poznawcze oraz nastrój, natomiast działania niepożądane były na ogół łagodne i obejmowały głównie zawroty oraz bóle głowy. W podsumowaniu badania wskazano jednak na konieczność dokładnego poznania mechanizmu działania THC i CBD odpowiadającego za ten terapeutyczny efekt (Wade i wsp., 2004).

W kolejnym randomizowanym, podwójnie zaślepionym badaniu Wade i wsp. oceniali skuteczność oraz bezpieczeństwo długotrwałego stosowania preparatów na bazie konopi. Do badania włączono 137 chorych z SM dowolnego typu, u których występował przynajmniej jeden z objawów: skurcze, spastyczność, ból, drżenie lub problem z pęcherzem. Podawano im preparat w postaci aerozolu stosowanego na śluzówkę jamy ustnej, którego pojedyncza dawka zawierała THC $(27 \mathrm{mg} / \mathrm{ml})$ oraz CBD (25 mg/ml). Pacjenci samodzielnie dostosowywali dzienną dawkę w zależności od ustąpienia objawów lub wystąpienia działań niepożądanych. Chorych oceniano co osiem tygodni, stosując głównie skalę VAS przez średnio 434 dni. Z badania wycofało się 58 osób (42,3\%) po średnio 225 dniach z powodu braku skuteczności stosowanego preparatu lub wystąpienia działań niepożądanych. W trakcie badania zgłoszono 292 działania niepożądane, takie jak: ból w obrębie jamy ustnej, nudności, biegunki, zawroty głowy, z czego ponad $80 \%$ miało charakter łagodny lub umiarkowany. U 3 pacjentów wystąpiły ciężkie działania niepożądane związane ze stosowaniem preparatu: nieżyt żołądka i jelit, zachłystowe zapalenie płuc, napad padaczkowy lub utrata równowagi. W przypadku 25 pacjentów odstawiono preparat na okres 2 tygodni, co nie spowodowało cięższych objawów odstawienia. U pozostałych badanych odnotowano złagodzenie objawów SM. Eksperyment ten nie pozwolił jednak na dokładne określenie skuteczności preparatu z konopi, w związku z czym konieczne było przeprowadzenie dodatkowych badań, mających również na uwadze wystąpienie działań niepożądanych u części chorych (Wade i wsp., 2006).
W 2010 roku Colin i wsp. przedstawili wyniki badania, w którym analizowali wpływ preparatu z konopi na złagodzenie spastyczności u chorych z SM. Podczas 15-tygodniowego badania opartego na metodzie podwójnie ślepej próby, w którym wzięło udział 337 pacjentów, stosowano preparat nabiksimol. Uzyskane wyniki wskazywały na znaczne złagodzenie spastyczności w grupie stosującej ten preparat w porównaniu z grupą placebo, a działania niepożądane miały na ogół charakter łagodny (Collin i wsp., 2010).

Celem badań prowadzonych przez Markovà i wsp. było określenie skuteczności stosowania preparatu kannabinoidowego jako dodatkowego elementu farmakoterapii u pacjentów z SM z umiarkowaną lub ciężką spastycznością. Do podwójnie zaślepionego badania włączono 191 osób. Uczestnicy badania stosowali przez okres 4 tygodni areozol zawierający THC i CBD w stosunku 1:1. W drugiej fazie badania 106 pacjentów zostało losowo przydzielonych do grupy badanej lub grupy placebo. Osoby z grupy badanej stosowały przez okres 12 tygodni ten preparat. W badaniu nie odnotowano poważnych działań niepożądanych. Uzyskane wyniki wskazywały na jego skuteczność w łagodzeniu spastyczności u chorych z SM. Wykazano lepszy efekt w łagodzeniu spastyczności w przypadku leczenia farmakologicznego połączonego ze stosowaniem tego preparatu w porównaniu z samą farmakoterapią (Markovà i wsp., 2019).

Langford i wsp. przeprowadzili badanie, w którym analizowali wpływ preparatów na bazie konopi na łagodzenie bólu neuropatycznego u pacjentów z SM. Do badania włączono 339 pacjentów z SM. Uczestnicy badania zostali losowo przydzieleni do grupy placebo oraz do grupy stosującej preparat THC - CBD. Okres obserwacji wynosił 14 tygodni. Uzyskane wyniki były niejednoznaczne. Zarówno w grupie placebo, jak i w grupie badanej zaobserwowano porównywalny efekt łagodzenia bólu. Przeprowadzono II fazę badania. Uzyskane wyniki nie przyniosły oczekiwanych rezultatów - wraz z wydłużeniem czasu leczenia bólu preparatami THC - CBD nie uzyskano żadnych efektów w porównaniu do grupy placebo. W związku z tym konieczne jest przeprowadzanie kolejnych badań klinicznych jednoznacznie określających efekt działania związków aktywnych w konopiach, powodujący redukcję bólu neuropatycznego (Langford i wsp., 2013).

Amerykańska Akademia Neurologii przedstawiła wyniki przeglądu badań z lat 1948-2013, obejmujących badania kliniczne oraz doświadczenia na zwierzętach dotyczące stosowania medycznej marihuany jako metody łagodzenia objawów stwardnienia rozsianego. $\mathrm{Na}$ podstawie analizy 34 badań wysunięto następujące wnioski dotyczące doustnych preparatów na bazie konopi, które działają:

- skutecznie / prawdopodobnie skutecznie w łagodzeniu spastyczności,

- prawdopodobnie nieskutecznie w zahamowaniu drżenia, 
- prawdopodobnie nieskutecznie/skutecznie w zaburzeniach pęcherza moczowego,

- skutecznie / prawdopodobnie skutecznie w redukcji bólu, z wyłączeniem bólu neuropatycznego (Koppel i wsp., 2014).

Przedstawione badania kliniczne dotyczyły zastosowania preparatów z konopi (THC/CBD) u osób ze stwardnieniem rozsianym jako dodatku do standardowej farmakoterapii. Nie odnotowano wpływu kannabinoidów na progresję SM, a jedynie łagodzenie objawów tej choroby, głównie spastyczności oraz bólu. U części chorych nie odnotowano działań niepożądanych, natomiast u pozostałych osób wystąpiły: bóle, zawroty głowy, wymioty, nudności. Nie udało się jednoznacznie określić skuteczności i bezpieczeństwa długotrwałego stosowania preparatu. Nie wiadomo, czy przy dłuższym stosowaniu nie pojawiałaby się tolerancja na kannabinoidy. Nieznane są również potencjalne interakcje z lekami.

\section{Choroba Parkinsona}

Choroba Parkinsona (ChP) jest jedną z najczęściej występujących chorób neurodegeneracyjnych, w której dochodzi do degeneracji komórek dopaminergicznych szlaku nigrostriatalnego. Leczenie ChP opiera się na leczeniu objawowym. Gdy u pacjenta pojawiają się trudności w codziennym funkcjonowaniu, podejmowana jest decyzja o wprowadzeniu farmakoterapii. U większości chorych odpowiednio dobrana farmakoterapia daje dosyć dobry efekt terapeutyczny i opóźnia wystąpienie powikłań ruchowych. Niestety w zaawansowanym stadium ChP działanie leków przestaje być efektywne. Biorąc pod uwagę mechanizmy degeneracji komórek dopaminergicznych oraz mechanizmy działania układu endokannabinoidowego, można przypuszczać, że poprzez działanie na receptory CB1 możemy uzyskać efekt neuroprotekcyjny oraz przeciwzapalny (Bogucki i wsp., 2014; Gaweł i Potulska-Chromik, 2015).

Mounsey i wsp. w swoim badaniu analizowali wpływ zwiększonego stężenia endokannabinoidu 2-arachidoniloglicerolu (2-AG) w mysim modelu ChP indukowanym neurotoksyną MPTP. 2-AG został podany w dawce 3 i 5 $\mathrm{mg} / \mathrm{kg}$. Dodatkowo zastosowano inhibitor enzymatycznej degradacji 2-AG. Wyniki badania wskazywały na hamowanie neurodegeneracji wywołanej MPTP przez 2-AG, co dowodzi, że system endokannabinoidowy mógł być zaangażowany w to neuroprotekcyjne działanie (Mounsey i wsp., 2015).

W innych badaniach wykazano, że zastosowanie agonistów receptora CB1 w doświadczalnym modelu ChP poprawiło motorykę zwierząt, jednakże odbywało się to prawdopodobnie poprzez mechanizmy nie dopaminergiczne, ale przez interakcje $\mathrm{z}$ adenozyną A2A i receptorami 5-HT (Kreitzer i Malenka, 2007). Zastosowanie antagonistów receptora $\mathrm{CB} 1$ było bardziej skuteczne i przyniosło poprawę funkcji motorycznych
- zmniejszyło akinezję i upośledzenie motoryki w eksperymentalnych modelach ChP (Gonzalez i wsp., 2006; García i wsp., 2011).

Przypuszcza się, że układ endokannabinoidowy może mieć wpływ na dyskinezy indukowane L-DOPĄ, chociaż wyniki badań przedklinicznych w tej kwestii były kontrowersyjne - wskazały, że zarówno agoniści, jak $i$ antagoniści receptora $\mathrm{CB} 1$ reprezentują potencjał jako czynniki antydyskinetyczne (van der Stelt i wsp., 2005).

Do chwili obecnej niewiele przeprowadzono badań klinicznych, w których analizowano wpływ kannabinoidów na objawy motoryczne i pozaruchowe u pacjentów z ChP. W niewielkim, randomizowanym, kontrolowanym placebo, podwójnie zaślepionym badaniu analizowano wpływ agonistów receptorów $\mathrm{CB} 1$ i CB2 na występowanie dyskinez indukowanych L-DOPĄ u pacjentów z ChP. Wykazano zmniejszenie objawu oraz całkowitego czasu dyskinez (Sieradzan i wsp., 2001). W innym niewielkim, randomizowanym, podwójnie zaślepionym badaniu trwającym 4 tygodnie analizowano wpływ doustnych podań wyciągu z konopi indyjskich (zawierający 1,25 mg CBD i 2,5 mg THC) u pacjentów z ChP. Wykazano, że stosowana terapia nie miała wpływu na dyskinezy, funkcje motoryczne, jakość życia oraz poprawę snu (Carroll i wsp., 2004).

Inne randomizowane badanie z podwójnie ślepą próbą, w którym analizowano wpływ CBD na poprawę funkcji motorycznych u pacjentów z ChP (bez zaburzeń psychicznych) oraz poprawę jakości życia, nie przyniosło jednoznacznych rezultatów. Do badania włączono 21 osób z ChP. Uczestników badania przydzielono losowo do 3 siedmioosobowych grup: I grupa otrzymywała CBD w dawce $75 \mathrm{mg} /$ dobę, II grupa CBD $300 \mathrm{mg} /$ dobę, III grupa placebo. Przez cały okres badania (6 tygodni) oceniano: funkcje motoryczne oraz jakość życia badanych. Uzyskane wyniki nie wskazywały na poprawę funkcji motorycznych, ale odnotowano pewną poprawę w grupie CBD 300 mg/dobę w zakresie jakości życia (Chagas i wsp., 2014).

W przeglądzie badań obejmującym zarówno badania kliniczne, jak i przedkliniczne Crippa i wsp. przedstawili analizę danych dotyczącą stosowania CBD u pacjentów z ChP oraz dane z badań przedklinicznych. Spośród czterech randomizowanych, kontrolowanych badań klinicznych, mających określić wpływ agonistów/antagonistów receptora kannabinoidowego 1 na łagodzenie zaburzeń ruchowych u osób z ChP tylko w jednym przypadku wykazano zmniejszenie dyskinezy indukowanej L-DOPA. Wykazano pozytywny efekt na objawy pozaruchowe. Badania te były krótkie i przeprowadzane na niewielką skalę, co ogranicza ich wiarygodność (Crippa i wsp., 2019).

Jest kilka istotnych czynników, które mogą decydować o powodzeniu terapii z zastosowaniem kannabinoidów w ChP, tj.: stadium choroby, stosowanie L-DOPY. Nie odnotowano natomiast poważnych zdarzeń niepożądanych 
podczas stosowania CBD. Obserwowane działania niepożądane to przede wszystkim: niedociśnienie, zawroty głowy, omamy wzrokowe, zawroty głowy i senność.

\section{Podsumowanie}

Kannabinoidy są biologicznie aktywnymi związkami wyizolowanymi z konopi, które różnią się strukturą, właściwościami oraz mechanizmem działania. Głównymi ich przedstawicielami są TCH oraz CBD. THC jest związkiem psychoaktywnym oraz wykazuje większe powinowactwo do receptorów kannabinoidowych. Receptory endokannabinoidowe CB1 oraz CB2 wchodzą w skład układu endokannabinoidowego, który bierze udział w prawidłowym funkcjonowaniu organizmu, wpływając na zachowanie wewnętrznej homeostazy. CB1 odpowiada głównie za prawidłowe przekaźnictwo nerwowe, natomiast CB2 odgrywa kluczową rolę w regulacji odpowiedzi zapalnej organizmu.

Potencjał terapeutyczny marihuany, czyli preparatu na bazie konopi indyjskich (Cannabis indica) jest znany od tysiącleci, jednak stosowanie go budzi wiele kontrowersji ze względu na działanie psychotyczne, wywoływane głównie przez zawarty w nim związek - THC. Z tego powodu marihuanie przypisuje się działanie narkotyczne oraz możliwość uzależnienia. Skutkiem tego są obowiązujące w wielu krajach zakazy stosowania, posiadania oraz uprawy konopi.

Analiza badań klinicznych dotyczących wpływu preparatów na bazie konopi na łagodzenie objawów epilepsji, głównie mieszanin THC i CBD, wskazuje na ich potencjalny efekt terapeutyczny w redukcji częstości napadów w przypadku padaczki lekoopornej u dzieci. Najwięcej pozytywnych wyników uzyskano u dzieci z zespołem Lennoxa-Gastauta lub Daveta.

W przeglądzie literaturowym obejmującym badania przedkliniczne oraz kliniczne brak wystarczających dowodów co do skuteczności preparatów na bazie konopi w łagodzeniu objawów u osób z SM. Część pacjentów zgłasza jednak poprawę swojego stanu w związku z redukcją bólu oraz spastyczności. W związku z tym Europejska Agencja Leków (EMA) zarejestrowała nabiksimol jako preparat, który może być stosowany jako dodatek do terapii spastyczności lub bólu, gdy standardowe leczenie farmakologiczne jest nieskuteczne.

Wpływ medycznej marihuany na łagodzenie objawów choroby Parkinsona jest w niewielkim stopniu udokumentowany. Większość przeprowadzonych badań ogranicza się do fazy przedklinicznej. Badań klinicznych jest nadal niewiele, a uzyskane wyniki nie dają wystarczających dowodów na zasadność stosowania medycznej marihuany.

Głównymi ograniczeniami dla zastosowania medycznej marihuany w terapii chorób jest brak jednoznacznych dowodów klinicznych na ich skuteczność. Należy także podkreślić, że kannabinoidy mogą istotnie zmieniać stężenia innych leków i wchodzić z nimi w nieopisane do tej pory interakcje. Ważne jest również informowanie pacjentów o możliwości wystąpienia działań niepożądanych, zarówno tych już znanych, jak i wcześniej nieraportowanych.
Conflict of interest and financial support non declared. / Nie zgłoszono konfliktu interesów oraz dofinansowania.

The work described in this article has been carried out in accordance with The Code of Ethics of the World Medical Association (Declaration of Helsinki) for experiments involving humans, EU Directive 2010/63/EU for animal experiments, and Uniform Requirements for manuscripts submitted to biomedical journals. / Treści przedstawione w artykule są zgodne z zasadami Deklaracji Helsińskiej, dyrektywami EU oraz ujednoliconymi wymaganiami dla czasopism biomedycznych.

Authors' contributions / Wkład autorów: KZ - literature search, manuscript perparing, acceptance of the final article version / zebranie piśmiennictwa, przygotowanie artykułu, akceptacja ostatecznej wersji artykułu; IJ-M - concept of the article, acceptance of the final article version / koncepcja i projekt pracy, content supervision, nadzór metytoryczny, akceptacja ostatecznej wersji artykułu; DM-G - content supervision, acceptance of the final article version / nadzór merytoryczny, akceptacja ostatecznej wersji artykułu

\section{References / Piśmiennictwo}

1. Adams R, Hunt M, Clark JH. Structure of Cannabidiol, a Product Isolated from the Marihuana Extract of Minnesota Wild Hemp. J Am Chem Soc 1940; 62 (1): 196-200.

2. AES Position Statement on Cannabis as a Treatment for Patients with Epileptic Seizure;

3. https://www.aesnet.org/sites/default/files/file_attach/ 42981132_cannabis_position_statement_updated_2.19.19. pdf (data cytowania 27.04.2020).

4. Baker D, Pryce G, Croxford JL, Brown P, Pertwee RG, Makriyannis A, et al. Endocannabinoids control spasticity in a multiple sclerosis model. FASEB J 2001; 15: 300-302.

5. Bergamaschi M, Queiroz, RH, Zuardi WA, Crippa, JA. Safety and Side Effects of Cannabidiol, a Cannabis sativa Constituent. Current Drug Safety 2011; 6(4): 237-249.

6. Bernal-Chico A, Canedo M, Manterola A, Sánchez-Gómez VM, Pérez-Samartín A, Rodríguez-Puertas R et al. Blockade of monoacylglycerol lipase inhibits oligodendrocyte excitotoxicity and prevents demyelination in vivo. Glia 2015; 63(1): 163-176. 
7. Bifulco M, Pisanti S. Medicinal use of cannabis in Europe, The fact that more countries legalize the medicinal use of cannabis should not become an argument for unfettered and uncontrolled use. EMBO reports 2015; 16: 130-132.

8. Bogucki A, Sławek J, Boczarska-Jedynak M, Gajos A, Opala G, Rudzińska $M$, et al. Leczenie zaawansowanej choroby Parkinsona - rekomendacje Polskiego Towarzystwa Choroby Parkinsona i Innych Zaburzeń Ruchowych. Pol Przegl Neurol 2014; 10(1): 15-22.

9. Carroll CB, Bain PG, Teare L. Cannabis for dyskinesia in Parkinson disease: a randomized double-blind crossover study. Neurol 2004; 63: 1245-1250.

10. Chagas MH, Zuardi AW, Tumas V, Pena-Pereira MA., Sobreira ET, Bergamaschi MM et al. Effects of cannabidiol in the treatment of patients with Parkinson's disease: an exploratory double-blind trial. J Psychopharmacol 2014; 28(11): 1088-1092.

11. Chiurchiùa V, Van der Steltc M, Centonzed D, Maccarrone M. The endocannabinoid system and its therapeutic exploitation in multiple sclerosis: Clues for other neuroinflammatory diseases. Progress in Neurobiol 2018; 160: 82-100.

12. Collin C, Ehler E, Waberzinek G, Alsindi Z, Davies P, Powell $\mathrm{K}$, et al. A double-blind, randomized, placebo-controlled, parallel-group study of Sativex, in subjects with symptoms of spasticity due to multiple sclerosis. Neurol Res 2010; 32(5): 451-459.

13. Collingwood L, O'Brien BG, Dreier S. Evaluating ballot initiative support for legalised marijuana: The case of Washington. Int J Drug Policy 2018; 56: 6-20.

14. Crippa JAS, Hallak JEC, Zuardi AW, Guimarães FS, Tumas V, Dos Santos RG. Is cannabidiol the ideal drug to treat non-motor Parkinson's disease symptoms. Eur Arch Psychiatry Clin Neurosci 2019; 269(1): 121-133.

15. Dąbrowska K, Miturska E, Moskalewicz J, Wieczorek Ł. Co mówią wyniki badań o szkodliwości zażywania marihuany? Przegląd badań. Serwis Info Narkomania 2012; 3(59): 33-38.

16. Devinsky O, Cross JH, Laux L. Trial of cannabidiol for drug-resistant seizures in the Dravet syndrome, N Engl J Med 2017; 376: 2011-2020.

17. Devinsky O, Marsh E, Friedman D, Thiele E, Laux L, Sullivan J, et al. Cannabidiol in patients with treatment-resistant epilepsy: an open-label interventional trial. Lancet Neurol 2016; 15(3): 270-278.

18. Foldy C. Presynaptic, Activity-Dependent Modulation of Cannabinoid Type 1 Receptor-Mediated Inhibition of GABA Release. J Neurosci 2006; 26(5): 1465-1469.

19. Frassinettia S, Mocciaa E, Caltavuturoa L, Gabrielea M, Longoa V, Bellania L i wsp. Nutraceutical potential of hemp (Cannabis sativa L.) seeds and sprouts. Food Chem 2018; 262: 56-66.

20. Gaoni Y, Mechoulam R. Isolation, Structure, and Partial Synthesis of an Active Constituent of Hashish, J Am Chem Soc 1964; 86 (8): 1646-1647.

21. Gaston TE, Bebin EM, Cutter GR, Liu Y, Szaflarski JP. Interactions between cannabidiol and commonly used antiepileptic drugs. Epilepsia 2017; 58(9): 1586-1592.

22. Gaweł M, Potulska-Chromik A. Choroby neurodegeneracyjne: choroba Alzheimera

23. i Parkinsona. Post N Med 2015: 28(7): 468-476.

24. Gerard CM, Mollereau C, Vassart G, Parmentier M. Molecular cloning of a human cannabinoid receptor which is also expressed in testis. Biochem J 1991; 279(1): 129-134.

25. Giancaspro GI, Kim NC, Venema J, de Mars S, Devine J, Celestino $\mathrm{C}$, et al. The Advisability and Feasibility of Developing
USP; https://www.uspnf.com/sites/default/files/usp_pdf/ EN/USPNF/usp-nf-notices/usp_stim_article_medical_cannabis.pdf (data cytowania 25.04.2020).

26. Gonzalez S, Scorticati C, Garcia-Arencibia M. Effects of rimonabant, a selective cannabinoid CB1 receptor antagonist, in a rat model of Parkinson's disease. Brain Res 2006; 1073-1074: 209-219.

27. García C, Palomo-Garo C, García-Arencibia M, Ramos J, Pertwee R, Fernández-Ruiz J. Symptom-relieving and neuroprotective effects of the phytocannabinoid $\Delta^{9}$-THCV in animal models of Parkinson's disease. Br J Pharmacol 2011; 163(7): 1495-1506.

28. Hall W, Degenhardt L. Adverse health effects of non-medical cannabis use. Lancet 2009; 374: 1383-1391.

29. Hussain SA, Zhou R, Jacobson C, Weng J, Cheng E., Lay J, et al. Perceived efficacy of cannabidiol-enriched cannabis extracts for treatment of pediatric epilepsy: A potential role for infantile spasms and Lennox-Gastaut syndrome. Epilepsy Behav 2015; 47: 138-141.

30. Jędrzejczak J, Majkowska-Zwolińska B, Ryglewicz D, Nagańska E, Mazurkiewicz-Bełdzińska M, Zalecenia Polskiego Towarzystwa Epileptologii dotyczące leczenia napadów padaczkowych u dorosłych. Aktualizacja. J Epileptology 2019; 27(1): 5-12.

31. Kaczmarczyk-Sedlak I, Wojnar W, Zych M, Dudek S. Lecznicze właściwości konopi i możliwości ich zastosowania w medycynie Katedra i Zakład Farmakognozji i Fitochemii, Wydział Farmaceutyczny z Oddziałem Medycyny Laboratoryjnej w Sosnowcu, Śląski Uniwersytet Medyczny w Katowicach 2017; https://katowice.oia.pl/files_news/news_7341/ files/Lecznicze_wlasciwosci_konopi_Kaczmarczyl_Sedlak_ Ilona_SUM_2017.pdf (data cytowania 25.04.2020).

32. Kilpeläinenb P, Kitunenb V, Lappalainena R, Tomppoa L, Väisänena T. Effect of steam treatment on the chemical composition of hemp (Cannabis sativa L.) and identification of the extracted carbohydrates and other compounds. Ind Crops Prod 2019; 131: 224-233.

33. Koppel BS, Brust JCM . Fife T, Bronstein J, Youssof S, Gronseth G, et al. Systematic review: Efficacy and safety of medical marijuana in selected neurologic disorders, Report of the Guideline Development Subcommittee of the American Academy of Neurology. Neurol 2014; 82(17): 1556-1563.

34. Kreitzer AC, Malenka RC. Endocannabinoid-mediated rescue of striatal LTD and motor deficits in Parkinson's disease models. Nature 2007; 445: 643-647.

35. Langford RM, Mares J, Novotna A, Vachova M, Novakova I, Notcutt W, et al. A double-blind, randomized, placebo-controlled, parallel-group study of THC/CBD oromucosal spray in combination with the existing treatment regimen, in the relief of central neuropathic pain in patients with multiple sclerosis. J Neurol 2013; 260(4): 984-997.

36. Legalizacja marihuany w Urugwaju; https://www.cannabisnews.pl/legalizacja-marihuany-w-urugwaju/ (data cytowania 20.04.2020).

37. Leizer C, Ribnicky D, Poulev A, Dushenkov S, Raskin I. The composition of hemp seed oil and its potential as an important source of nutrition. J Nutraceuticals, Functional \& Medical Foods 2000; 2(4): 35-53.

38. Marihuana rekreacyjna na świecie; https://www.cannabis news.pl/marihuana-rekreacyjna-na-swiecie/ (data cytowania 20.04.2020).

39. Markovà J, Essner U, Akmaz B, Marinelli M, Trompke C, Lentschat A, et al. Sativex as add-on therapy vs. further optimized first-line ANTispastics (SAVANT) in resistant 
multiple sclerosis spasticity: a double-blind, placebo-controlled randomised clinical trial. Int J Neurosci 2019; 129(2): 119-128.

40. Mathre ML. Cannabis in Medical Practice: A Legal, Historical and Pharmacological Overview of the Therapeutic Use of Marijuana, Wydawnictwo McFarland \& Company 1997, Jefferson, 3: 35-49.

41. Mauryaa N, Velmurugan BK. Therapeutic applications of cannabinoids, Chem-Biol Interact 2018; 293: 77-88.

42. Mikuriya TH. Marijuana in medicine: past, present and future. CalifMed. 1969; 110(1): 34-40.

43. Motyka M, Marcinkowski JT. Używanie pochodnych konopi. Część II. Zastosowanie w medycynie vs. konsekwencje zdrowotne. Probl Hig Epidemiol 2014; 95(1): 21-27.

44. Mounsey RB, Mustafa S, Robinson L, Ross RA, Riedel G, Pertwee RG, et al. Increasing levels of the endocannabinoid 2-AG is neuroprotective in the 1-methyl-4-phenyl-1,2,3,6tetrahydropyridine mouse model of Parkinson's disease. Exp Neurol 2015; 273: 36-44.

45. Munro S, Thomas KL, Abu-Shaar M. Molecular characterization of a peripheral receptor for cannabinoids. Nature 1993; 365: 61-65.

46. Oláh A, Tóth BI, Borbíró I, Sugawara K, Szöllõsi AG, Czifra $\mathrm{G}$, et al. Cannabidiol exerts sebostatic and antiinflammatory effects on human sebocytes. J Clin Invest 2014; 124(9): 3713-3724.

47. Pertwee RG. Cannabinoid pharmacology: the first 66 years, Br J Pharmacol 2006; 147(1): 163-171.

48. Perucca E. Cannabinoids in the Treatment of Epilepsy: Hard Evidence at Last. J Epilepsy Res 2017; 7(2): 61-76.

49. Porter BE, Jacobson C. Report of a parent survey of cannabidiol-enriched cannabis use in pediatric treatment-resistant epilepsy. Epilepsy Behav 2013; 29(3): 574-577.

50. Press CA, Knupp KG, Chapman KE. Parental reporting of response to oral cannabis extracts for treatment of refractory epilepsy. Epilepsy Behav 2015; 45: 49-52.

51. Przybek J, Członkowski A, Mirowska-Guzel D. Kannabinoidy w leczeniu stwardnienia rozsianego. MS Report 2017; 6/1(20): 21-26.

52. Rozenek H, Owczarek K. Warunki funkcjonowania chorych na padaczkę wpływające na jakość życia. Neurol Dypl 2010; 5(6): 37-43.

53. Russo E. Cognoscenti of Cannabis I: Jacques-Joseph Moreau (1804-1884). Journal of Cannabis Therapeutics 2001; 1(1): 85-88.

54. Ryan D, Drysdale AJ, Lafourcade C, Pertwee RG, Platt B. Cannabidiol targets mitochondria to regulate intracellular $\mathrm{Ca}^{2+}$ levels. J Neurosci 2009; 29(7): 2053-2063.

55. Scholten WK. The mechanism of action of cannabis and cannabinoids, Ned. Tijdschr. Geneeskd 2006; 150: 128-131.

56. Sieradzan KA, Fox SH, Hill M. Cannabinoids reduce levodopa-induced dyskinesia in Parkinson's disease: a pilot study. Neurol 2001; 57: 2108-2111.
57. Silska G. Konopie jako źródło kanabinoidów stosowanych w terapii. Post Fitoter 2017; 18(4): 286-289.

58. Siudem P, Wawer I, Paradowska K. Konopie i kannabinoidy. Farmacja Współcz 2015; 8: 1-8.

59. State Medical Marijuana Laws, National Conference of State Legislatures. June 27, 2018. Retrieved July 3, 2018.

60. van der Stelt M, Fox SH, Hill M. A role for endocannabinoids in the generation of parkinsonism and levodopa-induced dyskinesia in MPTP-lesioned non-human primate models of Parkinson's disease. FASEB J 2005; 19: 1140-1142.

61. Świątek M. Stwardnienie rozsiane - przyczyny, rodzaje, objawy i leczenie. GF 2016; 24-26.

62. Tennstedt D, Saint-Remy A. Cannabis and skin diseases. Eur J Dermatol 2011; 21(1): 5-11.

63. Thiele EA, Marsh ED, French JA, Mazurkiewicz-Beldzinska M, Benbadis SR, Joshi C, et al. Cannabidiol in patients with seizures associated with Lennox-Gastaut syndrome- a randomised, double-blind, placebo-controlled phase 3 tria. Lancet 2018; 391(10125): 1085-1096.

64. Touwn M. The religious and medicinal uses of Cannabis in China, India and Tibet. J Psychoactive Drugs 1981; 13(1): 23-34.

65. Ustawa z dnia 29 lipca 2005 r. o przeciwdziałaniu narkomanii; http://isap.sejm.gov.pl/isap.nsf/download.xsp/WDU 20051791485/T/D20051485L.pdf (data cytowania 1.05.2020).

66. Ustawa z dnia 7 lipca 2017 r. o zmianie ustawy o przeciwdziałaniu narkomanii oraz ustawy o refundacji leków, środków spożywczych specjalnego przeznaczenia żywieniowego oraz wyrobów medycznych; http://isap.sejm.gov.pl/isap.nsf/ download.xsp/WDU20170001458/T/D20171458L.pdf (data cytowania 2.05.2020).

67. Vetulani J. Lecznicze zastosowania marihuany. Wszechświat 2014; 115 (1-3): 15-24.

68. Vetulani J, Mazurek M. A w konopiach strach. Wydawnictwo PWN, Warszawa 2016.

69. Wachowiak R, Krawczyński M, Steinborn B. Stan aktualny i perspektywa stosowania kannabinoidów („medyczna marihuana”) w terapii dzieci. Przegląd opinii i stanowisk. Neurol Dziec 2016; 25(51): 55-65.

70. Wade DT, Makela P, Robson P, House H, Bateman C. Do cannabis-based medicinal extracts have general or specific effects on symptoms in multiple sclerosis? A double-blind, randomized, placebo-controlled study on 160 patient. Mult Scler 2004; 10: 434-441.

71. Wade DT, Makela P, House H, Bateman C, Robson P. Longterm use of a cannabis-based medicine in the treatment of spasticity and other symptoms in multiple sclerosis. Mult Scler 2006; 12 (5): 639-45.

72. Wojnar M. Standardy postępowania wobec osób używających nowych substancji psychoaktywnych (NSP). Poradnik dla pracowników medycznych, Warszawa 2018, 69-72.

73. Zuardi AW. History of cannabis as a medicine: a review. Rev Bras Psiquiatr 2006; 28 (2): 153-157. 
